by Qingchen Wang ${ }^{l, \#}$, Liangshu Shu ${ }^{2}$, Jacques Charvet ${ }^{3}$, Michel Faure ${ }^{3}$, Huadong Ma ${ }^{4}$, Boris Natal'in $^{5}$, Jun Gao ${ }^{1}$, Alfred Kroner ${ }^{6,7}$, Wenjiao Xiao ${ }^{1}$, Jinyi Li $^{8}$, Brian Windley ${ }^{9}$, Yan Chen ${ }^{3}$, Richard Glen ${ }^{10}$, Ping Jian ${ }^{7}$, W. Zhang ${ }^{7}$, Reimar Seltmann ${ }^{11}$, Simon Wilde ${ }^{12}$, Flavien Choulet ${ }^{3}$, Bo Wan ${ }^{1}$, Cameron Quinn ${ }^{10}$, Yamirka Rojas-Agramonte, ${ }^{6,}$, Qinghua Shang ${ }^{13}$, Wei Zhang ${ }^{7}$, Bo Wang ${ }^{2,14}$, Wei Lin ${ }^{1, *}$

\title{
Understanding and study perspectives on tectonic evolution and crustal structure of the Paleozoic Chinese Tianshan
}

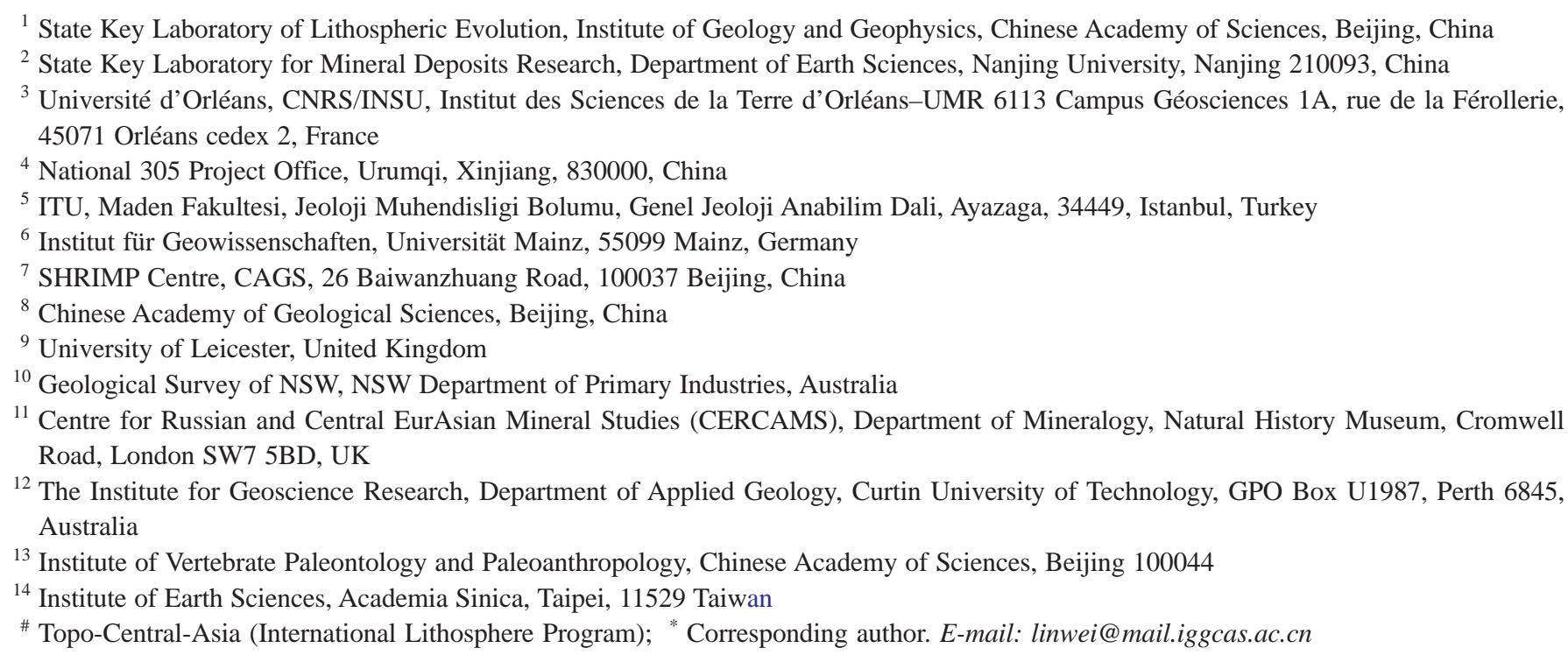

The Chinese Tianshan Belt is one of the key regions for the understanding of tectonics of the Central Asian Orogenic Belt (CAOB). An international field excursion and workshop were organized to conduct a common observation and discussion on the tectonic evolution of the Chinese Tianshan. This report summarizes the main achievements, including acknowledged geological features, controversial and remaining scientific problems, and discussion of a tentative geodynamic model. Thus, it is helpful to clarify what has been done in the past, what should be improved and what needs to be done in the future and therefore to better understand the tectonics of the Chinese Tianshan Belt and the CAOB as well.

\section{Introduction}

The Tianshan range is an important part of the Central Asian
Orogenic Belt (CAOB) that presents a typical example for accretion and collisional orogens. Its tectonic evolution is recently in hot debate and draws more and more attention of the international geological community. In order to promote scientific exchanges and make an effort to reach a common understanding of the Paleozoic geodynamic evolution of Tianshan and, therefore, of CAOB, a 7-day (Sept. 10 to 16, 2009) International Field Excursion across the Chinese Tianshan, southernmost part of the CAOB, was organized by the State Key Laboratory of Lithospheric Evolution (Chinese Academy of Sciences), State Key Laboratory for Mineral Deposits Research (Nanjing University), Institut des Sciences de la Terre d'Orléans (University of Orléans) and the Xinjiang 305 Project. The Excursion was initiated by International Lithosphere Program (ILP) CC-1/4 Project TOPOCENTRAL-ASIA and ERAS (Task Force 1), as well as Chinese National 973 project (2009CB825008) and Paleo-environment research of NW China. Integrating previous and recent field observations and laboratory analyses, the purpose of this excursion was to recognize the key tectonic zones, their geometric, kinematics and temporal relationships in order to reach a common understanding on the Paleozoic evolution of the Tianshan belt and to review updated models of continental accretion of Central Asia. Field-based 


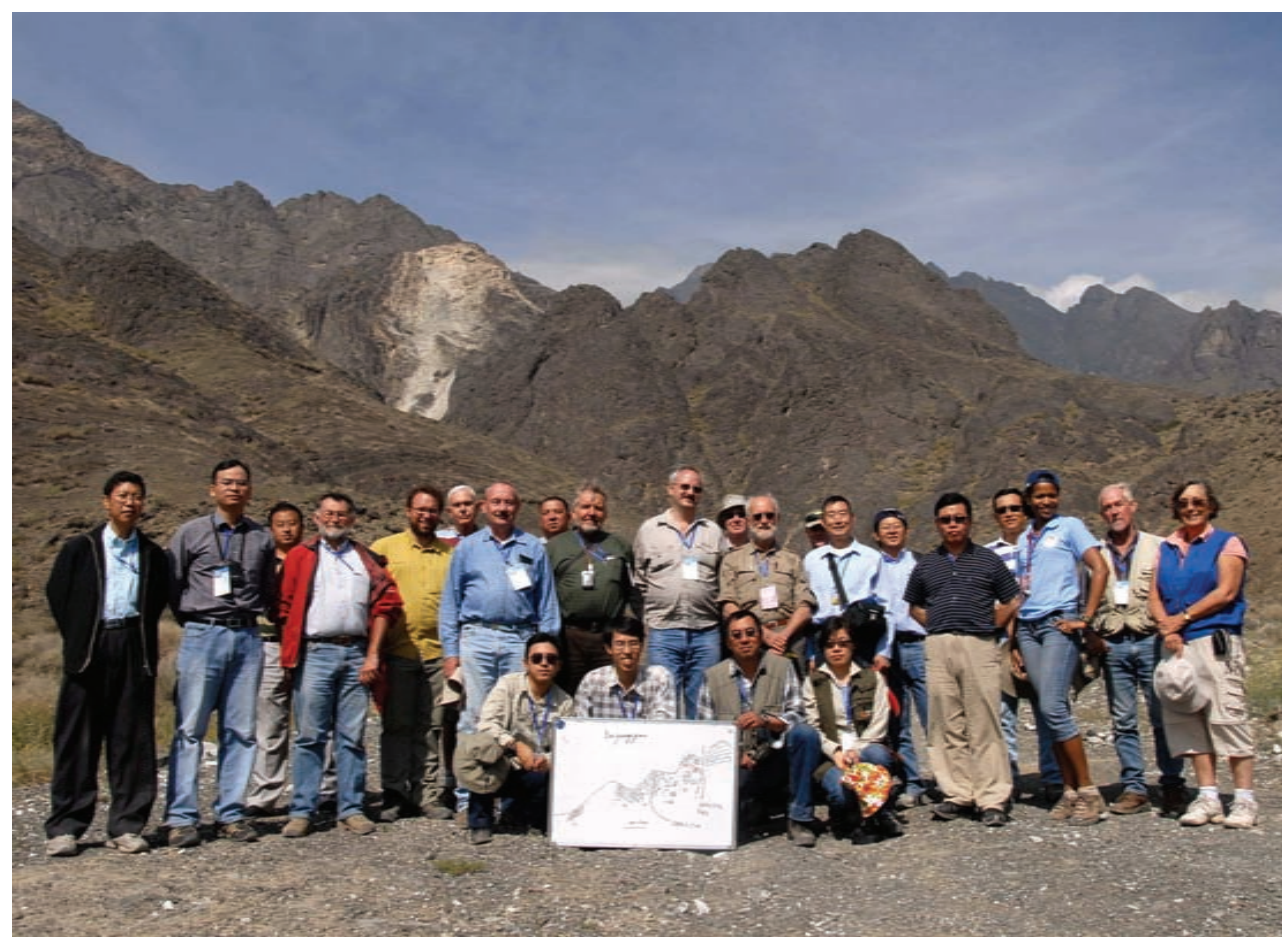

Photograph of the Permian Baiyanggou olistostrome including Carboniferous limestone blocks with variable sizes, and Permian terrigenous matrix (cf. Day 1 for the situation and the explanation in details). From left to right, rear: Dr. P. Jian; W.J. Xiao; M. Faure; F. Choulet; A. Kroner; J. Charvet; B. Natal'in; R. Seltmann; R. Glen; B. Windley; C. Quinn; Q. Wang, H. Ma, L. Shu; Y. Chen; Y. Rojas-Agramonte; S. Wilde; front: B. Wan; B. Wang; W. Lin; W. Zhang

siliceous muddy or terrigeneous matrix and transported as allochthons far away from the original sutures (e.g., Wang et al., 2010a and references therein). The interpretation of the Tianshan ophiolitic mélanges as representing three main sutures zones (i.e. disappeared oceans), which are, from South to North: (i) The South Tianshan, (ii) the Central Tianshan and (iii) the North Tianshan sutures zones was well constrained by stratigraphic, biostratigraphic, structural, geochemical, metamorphic and geochronologic data (e.g., LaurentCharvet, 2001; Wang, 2006; Charvet et al., 2007; Wang et al., 2006, 2008, 2010a and Lin et al., 2009) and thus might be today accepted by the scientific community.

\section{Continental blocks or microcontinents}

Several continental blocks or microcontinents are involved in the orogen. They are from South to North; (i) the Precambrian Tarim block, (ii) the Central Tianshan block,

discussions of the Tianshan Belt helped the participants to place the geodynamic evolution of this range within the general framework of Central Asian geology. Twenty-two scientists from 8 countries have participated in this 7-day field excursion (Photograph).

After the excursion, a 2-day workshop (Sept. 17 to 18, 2009) was held in Urumqi. The workshop provided an opportunity for participants to present new research results dealing with the various aspects of the geology of Central Asia and related areas, to exchange ideas for elaborated syntheses on the Paleozoic evolution of the Central Asian Orogenic Belts, and to set seeds for future international cooperation.

The following text summarizes the main points of the discussion that allowed the international geological community to understand the main geological features of the Chinese Tianshan orogen. However, several controversial questions remain and should be considered as targets for future work.

\section{Generally agreed features}

On the basis of effective discussion on the published data and field group observations during the excursion and workshop, a general agreement on the Paleozoic geology of the Chinese Tianshan can be reached on several important issues.

\section{Ophiolitic mélanges}

Several ophiolitic mélange zones are exposed in the Tianshan Belt (Fig. 1). Some of these represent suture zones (i.e. ancient plate boundaries), whereas others are oceanic elements included in a (iii) the Kazakh-Yili-North Tianshan block. The latter was formed by the Pre-Silurian amalgamation of several entities with accretionary prisms, continental and intra-oceanic arcs, and fragments of Precambrian continental crust (Allen et al., 1993; Mikolaichuk et al., 1997; Burtman, 2006; Windley et al., 2007).

\section{Continental magmatic arcs}

Two continental magmatic arcs represented by volcanic (i.e. lava flows, volcanic breccias, and agglomerates), volcaniclastic and pyroclastic rocks, and calc-alkaline plutons (granodiorite, diorite, and gabbro) are recognized in the Chinese Tianshan. (i) The largest magmatic arc is widely developed in the Kazakh-Yili-North Tianshan block. Stratigraphic and isotopic dating indicates that the North Tianshan arc formed in Devonian and Carboniferous times. (ii) Volcanic and sedimentary elements of an Early Paleozoic (OrdovicianEarly Devonian) arc are scattered in the northern part of the Central Tianshan block. Moreover, some of the early Paleozoic calc-alkaline granitic plutons that intrude the Central Tianshan block may represent the deep part of the same early Paleozoic arc. The Early Paleozoic arc was interpreted as resulting from the south-directed subduction under the northern margin of the Central Tianshan Block (Wang, 2006; Charvet et al., 2007; Wang et al., 2008, 2010a).

\section{Permian dextral strike-slip faulting}

Permian dextral strike-slip faulting is a major tectonic event (Laurent-Charvet et al., 2003) that induced several phenomena such as: (i) control of sedimentation in pull-apart and transtensional basins (Wartes et al., 2002; Shu et al., 2005, 2010; Wang et al., 2009), 


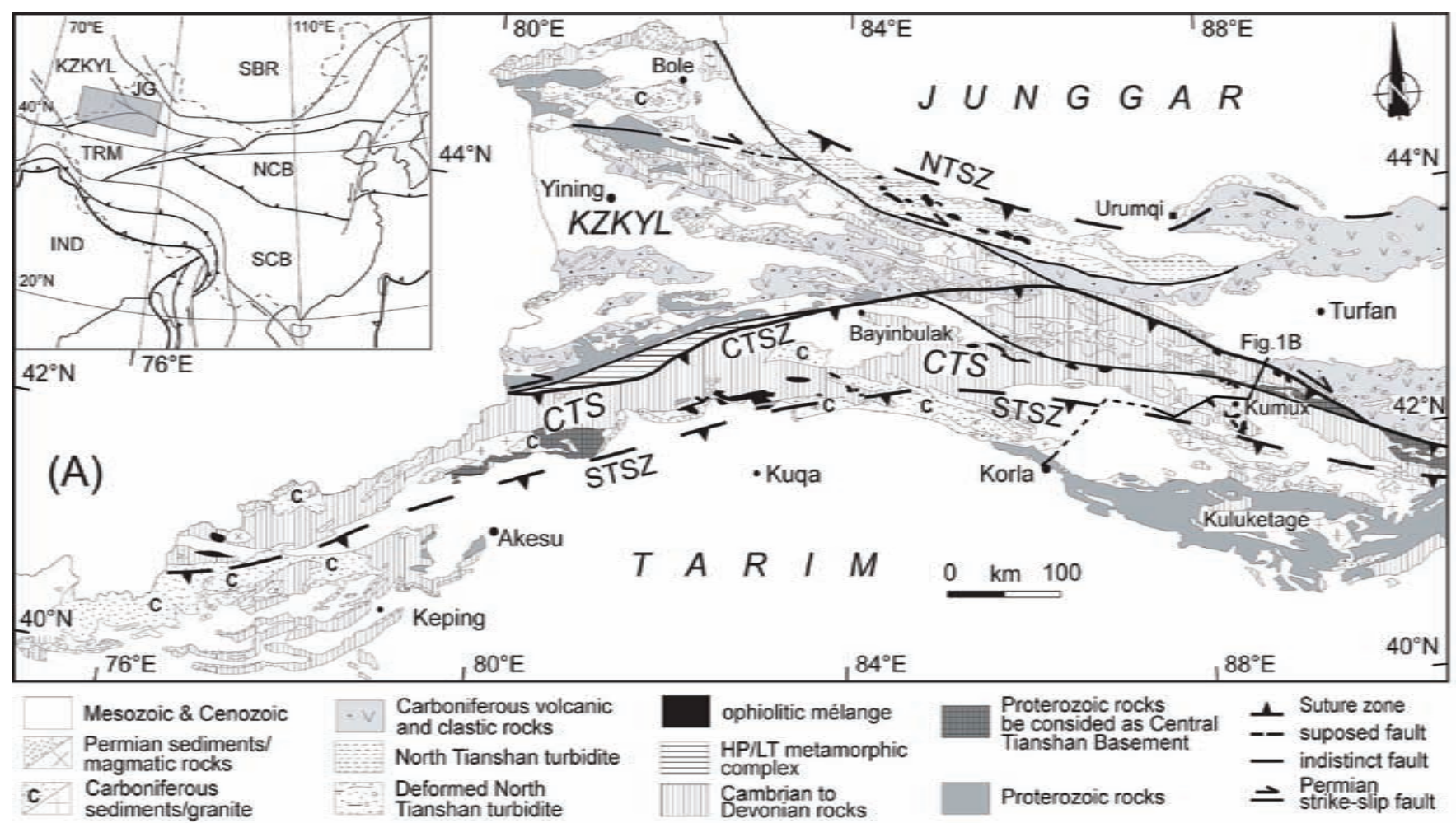

CTS: Central Tianshan Microcontinent, CTSZ: Central Tlanshan Suture Zone, NTSZ: North Tianshan Suture Zone, STSZ: South Tianshan Suture Zone, IND: India Plate, KZKYL: Kazakh-YII-North Tianshan Block, SBR: Siberia Plate, NCB: North China Block, SCB: South China Block, JGB: Junggar Block, TRM: Tarim Block.

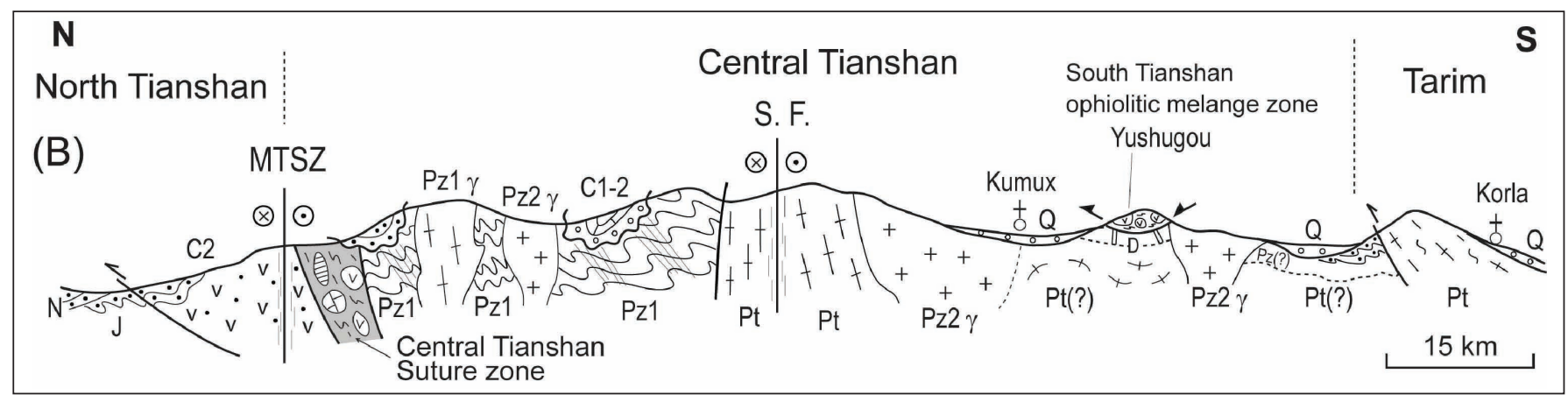

Figure 1. (A). Simplified geological map of the Chinese western Tianshan (modified from Wang et al., 2008; Lin et al., 2009). (B) Cross section of the Eastern Chinese Tianshan following the field excursion

(ii) development of alkaline magmatism (Yang et al., 1996, 2006; Wang et al., 2007d, 2009 and references therein), (iii) reworking of the ophiolitic mélange zones (Charvet et al., 2007, 2010; Wang et al., 2006, 2007c, 2010b), and (iv) fluid circulation and high thermal gradients responsible for ore deposits, retrogression of metamorphic rocks, and resetting of some radiometric ages (de Jong et al., 2009). The evolution of the Permian tectonic regime from transpression to transtension may also have produced a rather complex structural pattern (Laurent Charvet 2001; Wang Y. et al., 2008). In the Western Chinese Tianshan, two most important strike-slip faults are the Main Tianshan shear zone (MTSZ in Fig.1B) along the Central Tianshan Suture Zone (CTSZ in Fig.1A; Laurent-Charvet et al., 2002, 2003), several other ductile shear zones, characterized by subvertical foliation, horizontal stretching and mineral lineations, and dextral kinematic indicators, can be observed both in North and South Tianshan (Shu et al., 1999; Laurent-Charvet et al., 2002, 2003; Wang et al., 2006, 2007b, 2008, 2010b; Charvet et al., 2007; Lin et al., 2009).

\section{Controversial points and remaining questions}

In spite of the agreed features mentioned in the previous section, several points remain to be clarified. A non-exhaustive list is given below.

\section{Suture locations}

The Central Tianshan suture (CTSZ in Fig. 1A) separates the Kazakh-Yili-North Tianshan block to the North and the Central Tianshan block to the South. However, according to the different definition of Central Tianshan block, the 'Nikolaev Line' in Kyrgyzstan and Kazakhstan and the 'North Nalati Fault' in China was suggested as the suture zone between Kazakh-Yili-North Tianshan block and Central Tianshan block (Burtman, 1975; Gao et al., 2009; Qian et al., 2009 and references therein). More to the South, Atbashy- 
Inyl'chek Fault in Kyrgyzstan and South Nalati-Qawabulak Fault in China were considered as the boundary and suture zone between Central Tianshan block and Tarim block (Gao et al., 2009).

Another controversy is the recognition or not of suture zones in North and South Tianshan. Due to the strong Cenozoic tectonics, the South Tianshan suture (STSZ in Fig. 1A) was suggested to separate the Central Tianshan block to the North from the Tarim block to the South hidden below Mesozoic and Cenozoic formations. In the same way, the North Tianshan suture (NTSZ in Fig. 1A), lying between the Kazakh-Yili-North Tianshan and the Junggar blocks is a cryptic (Wang et al., 2006, 2008; Charvet et al., 2007; Lin et al., 2009).

\section{Age of $(U) H P$ metamorphism}

On the basis of structural evidence, high or ultra-high pressure metamorphism occurred mainly in the westernmost part of the belt and should date back to the Devonian or early Carboniferous (preVisean) (Wang et al., 2010 and references therein). However, radiometric data obtained from high-pressure minerals such as phengite often indicate middle to late Carboniferous ages (e.g., Gao and Klemd, 2003; Klemd et al., 2005). Even Triassic metamorphic zircon ages have been obtained (Zhang et al., 2007). Although these rather young ages can be explained by fluid-assisted crystallization or thermal resetting (de Jong et al., 2009), there is a need to reassess the age of (U)HP metamorphism. The main issue is in the geodynamic interpretation of the various ages: do they reflect prograde metamorphism during subduction or are they related to retrogression, uplift and cooling?

\section{Direction of subduction}

There is a consensus on (1) microstructure of top-to-the-North kinematics developed in the early Paleozoic Central Tianshan suture (Gao et al., 1995; Lin et al., 2009; Wang et al., 2010), and (2) bulk south-verging structures occurring to the south of the Central Tianshan suture (Windley et al., 1990; Allen et al., 1993), but which one should be considered as the indicator for the syn-accretionary kinematics remains disputed, and therefore the subduction polarity is still controversial. The important factor is that south-verging structures are widespread in both Paleozoic and Mesozoic rocks. Sometimes, this similar structure could be observed in the Cenozoic rocks (Allen et al., 1999; Yin et al., 1998). This implies that the Tianshan belt was reactivated by post-orogenic polyphase tectonics (Yin et al., 1998; Lin et al., 2009; Wang et al., 2010a). Furthermore, if the early Paleozoic magmatic arc developed in the Central Tianshan block and the occurrence of the South Tianshan back-arc basin are rather well supported by data, the closing history of the latter has to be confirmed (Zhu et al., 2008; Wang et al., 2008, 2010a). In the case of the South Tianshan suture, arc is not well preserved (cf. next point). However, the contact between the South Tianshan mélange and its tectonic substratum is associated with top-to-the-North kinematic indicators, also implying south-directed subduction (Charvet et al., 2007; Lin et al., 2009; Wang et al., 2010a). Detailed studies in the future should focus on the Upper Carboniferous clastic rocks that are shown on 1:200 000 scale geological maps along the southern side of Tianshan (Fig. 1A). Some maps suggest that the terrigenous sequence may contain blocks of limestones with Tethyan fusulinids, cherts, and ultramafic rocks (Zhu et al., 2007). In this case, this series might represent an accretionary prism related to the subduction of south Tianshan back-arc basin lithosphere. Clearly, the stratigraphy, structural style and kinematics of these rocks require further study.

\section{Active margin of Northern Tarim}

A magmatic arc that may be related to south-directed subduction and closure of the South Tianshan back-arc basin cannot be clearly identified in the northern part of the Tarim block. This apparent indigence of magmatism may be explained as follows: (1) Closure of the young Devonian back-arc basin may have taken place with very few or without the formation of a magmatic arc. (2) The arc may have been obliterated by Meso-Cenozoic reworking (Wang et al., 2010a). Nevertheless, several lines of evidence suggest an existence of Devonian calc-alkaline plutons which have recently been documented to the north of Kuqa and Kuluketage areas (Zhu, 2007; Zhu et al., 2008; Fig. 1A). A geochemical and geochronological study of these granitic plutons would be an important target for future investigations in order to constrain the potential existence of a Devonian arc on the Northern Tarim margin that was generally interpreted as a continued passive margin during the whole Paleozoic (e.g., Carroll et al., 1995; Gao et al., 1998; Xiao et al., 2004).

\section{Nature of the basement of the Junggar basin}

The Junggar basin currently contains a ca. $10 \mathrm{~km}$ thick sedimentary sequence of Carboniferous to Cenozoic deposits, but the underlying rocks are unknown. Knowledge of the nature of the basement is of particular importance to understand the geodynamic process during the orogeny of the Tianshan belt. A trapped oceanic plate or early Paleozoic island arc were favored according to geochemical and isotopic data from the magmatic rocks around the Junggar basin (Chen et al., 2000; Carroll et al., 2001; Zheng et al., 2006). However, a continental basement underlying the Junggar basin is not ruled out according to geophysical data and results of drill holes (Wang et al., 2000; Wang et al, 2004; He et al., 2008, 2010; Ji et al., 2010). No matter how, an intermediate crust including fragments of early Paleozoic magmatic arcs may also account for the late Carboniferous tectonics of the Kazakh-Yili-North Tianshan blocks. Seismic surveys and deep drilling will provide important information to answer this question.

\section{Existence of pre-Permian strike-slip faulting}

Permian dextral strike-slip faults are well developed, but the question of the pre-Permian strike-slip faulting remains open. Such a tectonic pattern might accommodate oblique plate convergence or account for the splitting of magmatic arcs.

\section{Pre-Cambrian and Early Paleozoic tectonics in the Kazakh-Yili-North Tianshan and in the Central Tianshan blocks}

These continental blocks obtained their bulk architecture in the Devonian, Carboniferous, and Permian during the formation of the Tianshan orogeny (Charvet et al., 2007; Wang et al., 2008 and reference therein). However, the Kazakh-Yili-North Tianshan and the Central Tianshan blocks contain Early Paleozoic and Proterozoic 
rocks that obviously experienced earlier deformations (e.g., Gao et al., 2009; Xu et al. 2010). For instance, the Terskey and Yili Early Paleozoic sutures as well as paired magmatic arcs recognized in Kyrgyzstan and Kazakhstan may extend eastwards into the Yili-North Tianshan block (Qian et al., 2009). The recognition of such preDevonian features will provide guidelines for the identification of the Gondwana-derived or Siberia-derived microcontinents and paleogeographic correlations throughout the Central Asia Orogenic Belt.

\section{Correlation and nomenclature of tectonic units}

Since the level of knowledge throughout the CAOB varies from one segment to the other, the Chinese Tianshan may become a key area showing the typical lithological, magmatic, structural, and metamorphic elements that can then also be recognized in the other segments of the CAOB (such as Kazakhstan and Kyrgyzstan). More locally, there is a need for correlation and harmonization of unit names, such as "South Tianshan" or "Central Tianshan" that are commonly used with different meanings depending on places and authors (Xiao et al., 1992; Gao et al., 1995, 1998, 2009; Charvet et al., 2007, 2010).

\section{Recognition of typical features of a collisional orogen and distinction between accretion-related and collision-related structures}

Although continental subduction and collision have certainly played a major role in the evolution of the Tianshan orogen, several typical elements observed in other collisional belts such as the Himalaya, the Alps or the Variscan belts are not yet clearly recognized yet. Some of these lacking features are: (i) widespread crustal melting characterized by leucogranitic or peraluminous plutonism, (ii) synand post-orogenic collapse with ductile normal faults that induced the exhumation of the high-grade metamorphic rocks, (iii) foreland basins filled by terrigeneous rocks derived from the erosion of the rising orogen. Whether these elements are really missing or were not yet recognized in the Tianshan remains an open question.

Since both accretionary complexes and nappe structures are represented in the Tianshan belt, it would be important to be able to separate two structural styles, and evaluate, through thermo-barometric studies, the physical conditions of their development.

\section{A tentative geodynamic model}

In spite of the pending questions mentioned above and the debates which are still on-going on the mechanism and timing of the agglomeration of Central Asia, after a comprehensive analysis on the published data during last several decades in different aspects of structural geology, geochemistry, geochronology and geophysics, a review of some up-dated models was conducted mainly focusing on the subduction polarity and age of accretion/collision, and a preliminary geodynamic model for the evolution of the Chinese Tianshan can be proposed. Some controversial points related to the above-discussed questions need further testing by future multidisciplinary research. In this tentative model, the Paleozoic evolution of the Chinese Tianshan can be separated into five main stages (Fig. 2).
(1) Subduction of the Central Tianshan Ocean $\left(\mathrm{O}-\mathrm{S}_{2}\right)$

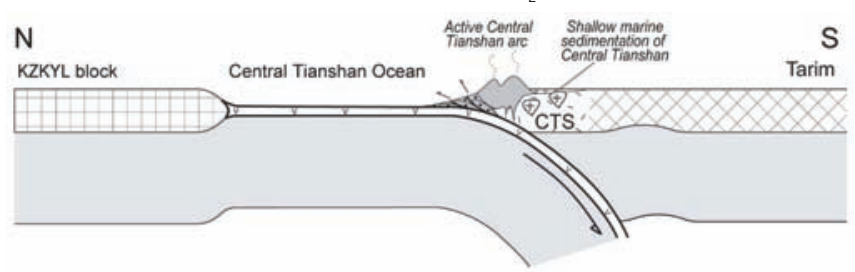

(2) Continental collision, exhumation of HP metamorphism rocks and opening $\mathrm{N}$ of the South Tianshan back-arc basin $\left(\mathrm{S}_{2}-\mathrm{C}_{1}\right)$

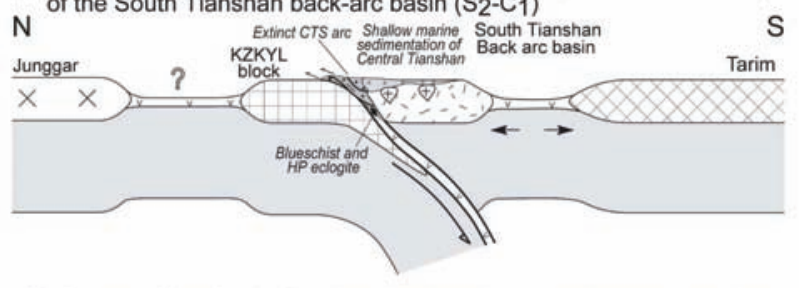

(3) Closure of the South Tianshan back-arc basin and occurrence of arc magmatism in the north margin of Yili-Kazakhstan block(before $\mathrm{C}_{2}$ )

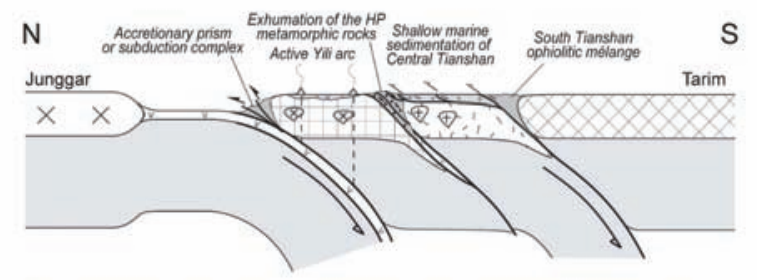

(4) Thrusting related to the closure of the Junggar Ocean $\left(C_{3}-P_{1}\right)$
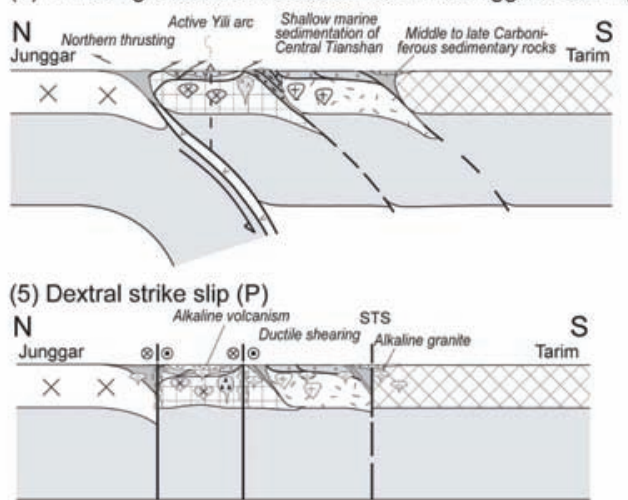

Figure 2. A tentative geodynamic model for the Paleozoic Chinese Tianshan (modified from Wang et al., 2008; Lin et al., 2009)

\section{Early Paleozoic closure of the Central Tianshan Ocean}

The Central Tianshan oceanic basin separating the Tarim and Kazakh-Yili-North Tianshan block began to close in the Ordovician. The closure was achieved by a south-directed subduction below the Tarim block. During Late Silurian-Middle Devonian, the northern margin of the Tarim block experienced extensional tectonism that was responsible for the formation of the South Tianshan back-arc basin.

\section{Early Carboniferous collision between the Kazakh- Yili-North Tianshan and Central Tianshan blocks}

This early collision in the evolution of the Tianshan orogen that can be called the "Eo-Tianshan phase" was responsible for the development of the high to ultra-high pressure metamorphism along the Central Tianshan suture. The collision followed oceanic 
lithosphere consumption and deep subduction and was coeval with top-to-the-North ductile shearing.

Late stage of Early Carboniferous closure of the South Tianshan back-arc basin, and formation of the North Tianshan magmatic arc

The continental collage formed by the welding of the KazakhYili-North Tianshan and Central Tianshan blocks collided with the Tarim block and induced closure of the South Tianshan back-arc basin. Sedimentary rocks (chert, siliceous mudstone, limestone), remnants of the oceanic crust (pillow lava, diabase, gabbro), and the underlying mantle (serpentinized peridotite) of the South Tianshan back-arc basin mixed together with sedimentary rocks of the Tarim block, formed the South Tianshan ophiolitic melange. Presently, this unit crops out as klippes emplaced from South to North upon the Central Tianshan block. More to the north, high pressure eclogitic rocks that had formed along the Central Tianshan suture are retrogressed into greenschist facies conditions during their exhumation. Lastly, the northern boundary of the Kazakh-Yili-North Tianshan block became an active margin along which the North Tianshan accretionary complex, including the North Tianshan ophiolitic melange, and the North Tianshan magmatic arc developed.

\section{Late Carboniferous tectonics in the Kazakh-Yili- North Tianshan block}

Most of the tectonic activity was located in the Kazakh-Yili-North
Tianshan block. The end of North Tianshan arc magmatism is interpreted as the consequence of subduction of the Junggar basement. In the Central Tianshan, late Carboniferous sedimentation is represented by shallow marine terrigeneous and carbonated rocks. Tectonically, South-directed thrusts and folds that developed in the Kazakh-Yili-North Tianshan and Central Tianshan blocks can be viewed as resulting from back-folding and thrusting due to the chocking of the north Tianshan subduction.

\section{Permian dextral strike-slip faulting}

The various tectonic elements, including magmatic arcs, continental blocks, and ophiolitic melanges, were already welded together at the end of the Carboniferous. In Permian times, all these units experienced major dextral wrenching parallel to the strike of the orogen. To the north, the Altai Fold Belt underwent sinistral strikeslip faulting. The two strike-slip systems accommodated an opposite motion of Tarim and Siberia as indicated by paleomagnetism. This strike-slip tectonics was accompanied by pull-apart basin opening and post-tectonic magmatism expressed by volcanic rocks and granitic plutons. The coeval emplacement of Permian calc-alkaline and alkaline suites is noteworthy in Tianshan, showing the influence of the mantle metasomatism during the Carboniferous subduction.

During the Mesozoic, deformation resumed, as documented by Triassic and Jurassic unconformities. But these tectonic events were purely intra-continental, like the Cenozoic event responding to the Asia-India collision.

\title{
Appendix
}

\section{Guidebook for the International Geological Excursion in the Paleozoic Chinese Tianshan (Sept. 10 to 16, 2009)}

\author{
Bo Wang ${ }^{1}$, Wei Lin ${ }^{2}$, Jacques Charvet ${ }^{3}$, Michel Faure ${ }^{3}$, Lianshu Shu ${ }^{1}$ and Domique Cluzel ${ }^{4}$ \\ ${ }^{1}$ State Key Laboratory for Mineral Deposits Research, Department of Earth Sciences, Nanjing University, Nanjing 210093, China \\ ${ }^{2}$ State Key Laboratory of Lithospheric Evolution, Institute of Geology and Geophysics, Chinese Academy of Sciences, Beijing, China \\ E-mail:linwei@mail.iggcas.ac.cn \\ ${ }^{3}$ Université d'Orléans, CNRS/INSU, Institut des Sciences de la Terre d'Orléans-UMR 6113 Campus Géosciences 1A, rue de la \\ Férollerie, 45071 Orléans cedex 2, France \\ ${ }^{4}$ Pole Pluridisciplinaire de la Matière et de l'Environnement, Université de la Nouvelle-Calédonie, 98851 Nouméa, New Caledonia
}

\section{PART I: A GEOLOGICAL OUTLINE}

\section{Introduction}

The Tianshan Belt is a major orogenic domain within the Central Asian Orogenic Belt (CAOB) (e.g. Jahn et al. 2000, 2004; Jahn 2004; Xiao et al. 2004; Kröner et al. 2007; Windley et al. 2007) or Altaid orogenic collage (Sengör et al. 1993; Sengör and Natal'in 1996). It is bounded by the Kazakhstan microcontinent to the northwest, the Junggar basin to the northeast, and the Tarim basin to the south (Coleman 1989; Xiao et al. 1992; Konopelko et al. 2007; Kröner et al. 2008 and references therein, Fig.1). It extends east-west for over
$2500 \mathrm{~km}$ and exhibits the highest relief in Central Asia. The present topography is due to Tertiary Asia-India collision (Tapponnier et al. 1986; Nelson et al. 1987; Avouac et al. 1993; Sobel and Dumitru 1997). In addition, Cenozoic tectonism is responsible for the recent northward underthrusting of Tarim below the South Chinese Tianshan, and for the southward underthrusting of Junggar below the North Tianshan (Windley et al. 1990; Avouac et al. 1993; Hendrix et al. 1994; Burchfiel et al. 1999; Allen et al. 1999; Li et al. 2009). From the Neoproterozoic to late Paleozoic, accretion of several continental blocks, island arcs and accretionary complexes to the southern margin 


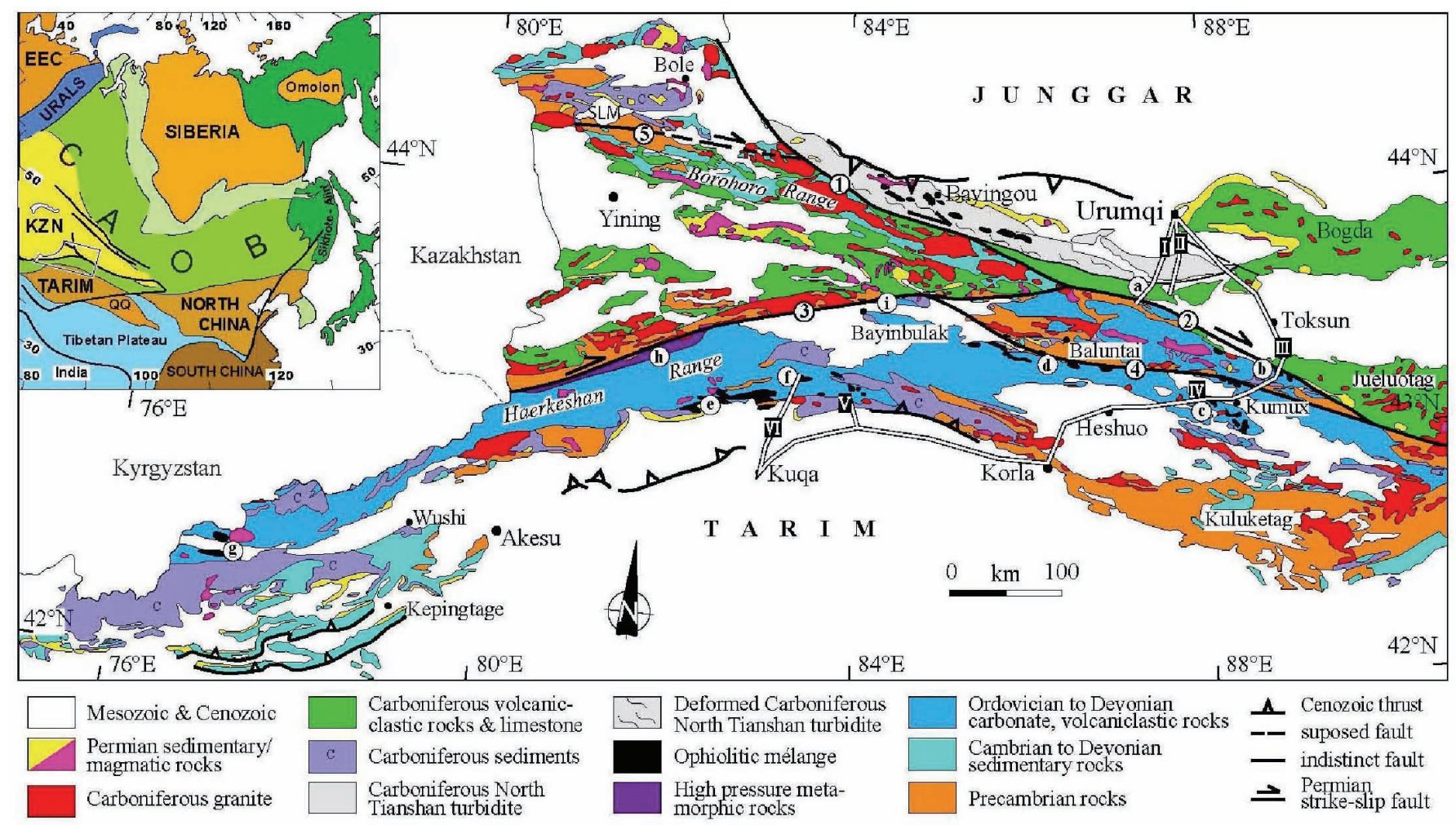

Figure 1. Geological map of the Chinese western Tianshan belt (modified after Wang et al., 2008). Numbers in circle refer to the main faults: 1-North Tianshan fault (NTF); 2-Main Tianshan shear zone (MTSZ); 3-Qingbulak-Nalati fault (QNF); 4-Sangshuyuanzi fault; 5-Jinghe fault. Letters correspond to localities cited in the text: a. Houxia; b. Gangou-Mishigou; c. Yushugou; d. Guluogou-Wuwamen; e. Heiyingshan; f. Kulehu; g. Aheqi; h. Kekesu; i. Nalati. Roman numbers stand for the excursion sections: I-Houxia section; II-Aiweiergou section; III-Gangou section; IV-Yushugou section; V-Cedaya section; VI-Duku road section. Inset shows location of the Tianshan Belt in Central Asia (modified from Jahn, 2004). Abbreviations: CAOB: Central Asian Orogenic Belt; EEC: Eastern European Craton; KZN: Kazakhstan; QQ: Qaidam-Qinling.

of Eurasia formed the CAOB, within which the Tianshan Belt resulted from amalgamation of the Tarim, Junggar and Kazakh-Yili-North Tianshan blocks and intervening microcontinents (Wang et al. 1994; Gao et al. 1998; Chen et al. 1999; Charvet et al. 2007; Wang et al. 2008; Windley et al. 2007).

According to previous works (e.g. Windley et al. 1990; Allen et al. 1993; Gao et al. 1998; Chen et al. 1999), several ophiolitic belts were used to define an Early Paleozoic South Tianshan Suture (STSS, corresponding to faults 3 and 4 in Fig. 1) and a Late Paleozoic North Tianshan suture (NTSS, corresponding to faults 1 and 2 in Fig. 1), dividing the Chinese Tianshan belt into North Tianshan, Central Tianshan and South Tianshan zones. In the literature, there is often confusion between a suture zone that represents a plate boundary and a strike-slip fault that reworked the plate boundaries during Permian, i.e. after accretion and collision.

The tectonic evolution of this complex orogen remains controversial, and numerous geodynamic models have been proposed during the last two decades. According to Coleman (1989), the Tianshan resulted from the closure of an oceanic basin during the early Paleozoic. Ma et al. (1993) suggested that the southern Tianshan evolved from a back-arc basin that formed by southward subduction of the Paleo-Junggar Oceanic lithosphere, whereas Cao et al. (1992) considered that the southern Tianshan represents oceanic crust thrust to the south upon the Tarim Block during the late Paleozoic. According to Windley et al. (1990) and Allen et al. (1993), north-directed subduction occurred in the eastern Chinese Tianshan along the STSS during the late Devonian-early Carboniferous, whereas south-directed subduction occurred in the late Carboniferous-early Permian along the NTSS. In the western Tianshan, Gao et al. $(1995,1998)$ proposed a north-directed subduction along the southern Tianshan suture zone. According to Chen et al. (1999), the southern Tianshan originated from the closure of an early Paleozoic ocean located between Tarim and the Central Tianshan and subsequent late Paleozoic oblique collision. More recently, Charvet et al. (2007), Wang et al. (2008), and Lin et al. (2009) argued that the Paleozoic Chinese Tianshan is a polyphase orogenic belt formed by the closure of three oceanic basins that separated four continental blocks, namely from north to south, Junggar, Yili-North Tianshan, Central Tianshan, and Tarim. The three subduction systems were not coeval, but all directed to the south. In the following discussion, the main tectonic units are presented from the north to south.

\section{The Yili-North Tianshan Domain}

\section{The North Tianshan accretionary prism}

In the North Tianshan, two lithotectonic units can be identified, namely a Carboniferous turbidite and an ophiolitic mélange well exposed at Bayingou (Wang et al. 2006; Fig. 1). The turbidites are developed in an area of 300-km long and 20-km wide and consist of sandstone and black argillite alternations. Sandstone presents typical Bouma sequences and the thickness of sandstone beds varies from a few centimeters to 1 meter (XJBGMR 1993; Wang et al. 2006). 
Terrigenous, siliceous and calc-alkaline magmatic clasts were observed in sandstone and conglomerates, and deep-water ichnofossils indicate that the turbidites were deposited in a fore-arc deep-sea environment (Wang et al. 2006). The southern part of the turbidite, along the NTF, exhibits a subvertical slaty cleavage with a subhorizontal mineralstretching lineation. Kinematic observations indicate a dextral ductile shearing related to the NTF (Fig. 1). Biotite in slates yields a ${ }^{40} \mathrm{Ar} /{ }^{39} \mathrm{Ar}$ age of $275-245 \mathrm{Ma}$ indicating the time of the dextral shearing (de Jong et al. 2009). This Permian age is consistent with that of the Main Tianshan shear zone (Fig. 1; Shu et al., 1999; Laurent-Charvet et al. 2002, 2003; Wang Y. et al. 2008).

The Bayingou ophiolitic mélange is discontinuously developed in a $250 \mathrm{~km}$ long and $5 \sim 15-\mathrm{km}$ wide area and crops out within the turbidite. It consists of serpentinized peridotite, gabbro, diabase, basalt, chert, plagiogranite and rare limestone blocks enclosed in a sheared matrix made of black or red mudstone and light-yellow-green greywacke. Famennian-Visean microfossils have been found in cherts (Xiao et al. 1992; Li and Du 1994), and zircon U-Pb ICPMS or SHRIMP ages of 344-325 Ma are obtained from Bayingou gabbro and plagiogranite (Xu et al. 2005, 2006a), both indicate late Devonian to late Early-Carboniferous ages for the ophiolitic rocks. Petrological and geochemical studies show that the mafic rocks were formed in an oceanic basin (Wu et al. 1989; Xiao et al. 1992; Li and Du 1994). Structural analysis indicates that both blocks and matrix were deformed by north-directed shearing (Wang et al. 2006). Recent SHRIMP zircon U-Pb dating on the A-type granite that intrudes the North Tianshan suture yielded an age of $316 \pm 3 \mathrm{Ma}$, suggesting that the subduction and accretion events in North Tianshan terminated in Late Carboniferous (Han et al. 2010).

\section{The Yili-North Tianshan Late Paleozoic magmatic arc}

In the western part, this unit is mainly composed of Carboniferous limestone and sandstone associated with andesite, rhyolite, trachyte, tuff and minor basalt (Fig. 1; XJBGMR 1993). Synchronous plutons of gabbro, granodiorite, tonalite, K-granite, pegmatite and aplite dykes are well developed. The Carboniferous rocks are lithologically similar throughout the Yili area (Fig. 1). Trace elements geochemistry and isotopic studies indicate that the magmatic rocks are calc-alkaline in composition and were generated in an active continental margin (Chen et al. 2000a; Zhu et al. 2005, 2006; Wang et al. 2007b). Zircon U-Pb dating of the magmatic rocks (SHRIMP/ICPMS) yield 363-300 Ma ages indicating that these arc-type rocks formed during Late Devonian to latest Carboniferous (Zhu et al. 2005; Xu et al. 2006a; Wang et al. 2006; Zhai et al. 2006; Gao et al. 2008). To the west of Urumqi, the magmatic arc is almost undeformed except locally along the Qingbulak-Nalati fault where dextral ductile shearing occurred around 270-250 Ma (Yin and Nie 1996; Zhou et al. 2001).

To the east of Urumqi, greywackes, red porphyritic andesite, basalt, and limestone are developed in the Bogdashan. It corresponds to the eastern extension of the North Tianshan arc. This unit is deformed by hundred-meters scale upright or north-verging folds and north directed reverse faults, but it disappears beneath the unconformably overlying Upper Jurassic coarse sandstones and conglomerates that can be observed along the Houxia and ToksunKumux sections (Fig. 1) and other parallel N-S sections more to the east (Charvet et al. 2007). The volcanic rocks of the North Tianshan arc are often associated with Mid-Carboniferous tightly folded meterscale beds of grey and brown fossiliferous limestone and sandstone with minor red pelite, assigned to the Lower Carboniferous (Ma et al. 1997; Shu et al. 2000; Laurent-Charvet 2001; Xiao et al. 2004; Charvet et al. 2007). Granitic rocks are also developed in these areas and formed during the late Devonian to Carboniferous (383-310 Ma, zircon U-Pb ages) (Yang et al. 1996, 2000; Ma et al. 1997; Qin et al. 2000, 2002; Li et al. 2003). The basement of the Bogda arc is not exposed and remains unknown.

\section{The Yili-North Tianshan basement}

The Yili-North Tianshan magmatic arc is situated above a Proterozoic basement and an Early Paleozoic sedimentary cover. The basement rocks crop out along the boundaries of the Yili Block (Fig. 1). The Meso- to Neoproterozoic carbonates and clastic rocks of the Jixian and Qingbaikou formations are developed in the north of the Borohoro range and to the south of Yining. Neoproterozoic red sandstone and minor "tillite" (XJBGMR 1993; Gao et al. 1998; Xia et al. 2002) are exposed to the south of Sailimu Lake (Fig. 1). Precambrian amphibolite facies metamorphic rocks mainly crop out in the Bingdaban-Baluntai area, south of Urumqi. They were also recognized at Nalati Pass, north of Bayinbuluk, and to the north of the Haerke Mountains (Fig. 1), where orthogneiss yield zircon U-Pb ages at 882 and $709 \mathrm{Ma}$ (Chen et al. 2000b, 2000c). The early Paleozoic strata are mainly Cambrian and Ordovician chert and carbonates occurring in the Borohoro range, the northern margin of the Yili Block (Fig. 1).

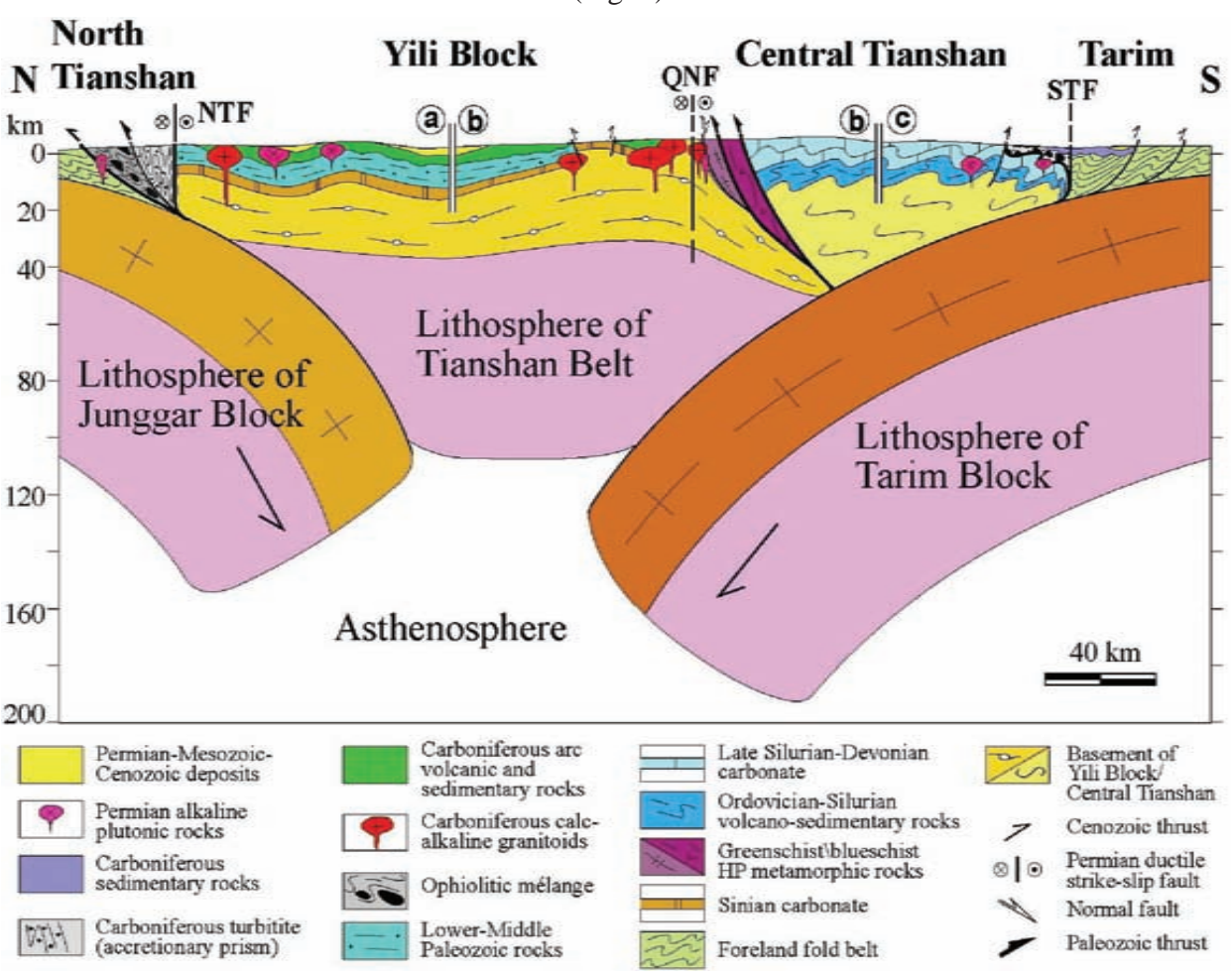

Figure 2. Interpretative cross section of the Yili Block and its boundaries (from Wang et al., 2008). 
The Precambrian basement of the Yili triangular area was generally considered as a microcontinent corresponding to the western part of the Yili-Central Tianshan Plate (e.g. Xiao et al. 1992; Allen et al. 1993; Gao et al. 1998; Zhang et al. 2007), whereas, it was regarded as the "North Tien Shan-Ili Plate" in Kazakhstan and Kyrgyzstan (Mikolaichuk et al. 1995; Konopelko et al. 2007). Recent studies also suggest that the Yili Block is distinct from the Central Tianshan (Charvet et al., 2007; Wang et al. 2007c, 2008; Gao et al. 2009; Qian et al. 2009). However, an ambiguity exists regarding the definition of the "Yili Block" and its boundary with the Central Tianshan. The main characteristic of this block is the presence of a series of an Upper Paleozoic (Late Devonian- Carboniferous) pile of sedimentary rocks and abundant arc volcanic and plutonic rocks, while the Central Tianshan is characterized by the occurrence of Early Paleozoic arctype magmatic rocks and late Paleozoic sedimentary and postcollisional plutonic rocks (e.g. XJBGMR 1993; Xu et al. 2006a; Wang et al. 2008; Gao et al., 2009).

\section{(U)HP metamorphic belt and related ophiolites along the southern margin of the Yili-North Tianshan Block}

\section{The SW Chinese Tianshan (U)HP/LT metamorphic belt}

The SW Chinese Tianshan (U)HP/LT metamorphic belt mainly consists of blueschist- and greenschist-facies mafic and metapelitic rocks. Silurian marble lenses and slices of ultramafic rocks represent exotic blocks included in a mélange that is interpreted as an accretionary wedge on the southern side of the Kazakh-Yili-North Tianshan Block (Gao et al. 1999). According to previous tectonic studies, the (U)HP metamorphic rocks formed during the subduction of oceanic lithosphere of the Tianshan Paleo-ocean beneath the Kazakh-Yili-North Tianshan (Gao et al. 1995, 1998, 2000, 2006; Volkova and Budanov 1999; Gao and Klemd 2003; Klemd et al. 2005; Zhang et al. 2007). Protoliths are MORB and OIB basalts, mafic volcaniclastic rocks, and deep-sea sediments representing an oceanic crust (Gao et al. 1995; Gao and Klemd 2003). This metamorphic complex extends southwestward to Kyrgyzstan and Tajikistan (Dobretsov et al. 1987; Tagiri et al. 1995; Volkova and Budanov 1999). Kinematic analyses of these (U)HP metamorphic rocks and the underlying gneiss indicate top-to-the-north shearing (Gao et al. 1995; Wang et al. 2007a, 2010; Lin et al. 2009). This northward shearing was firstly interpreted as resulting from the exhumation of HP metamorphic rocks (Gao et al. 1995). However, the south dipping foliation and the kinematic consistency in the HP metamorphic rocks better fit with the interpretation of northward thrusting of oceanic rocks upon the Yili continental basement (Lin et al. 2009; Wang et al., 2010). Radiometric ages of greenschists and blueschists reveal an important retrogression that occurred around $310 \mathrm{Ma}$ (Gao and Klemd 2003; Klemd et al. 2005; Wang et al. 2010). Despite the formation of an Ordovician-Devonian magmatic arc due to subduction of oceanic lithosphere (Laurent-Charvet 2001; Ma et al., 2006; Charvet et al., 2007), isotopic ages for blueschists and eclogites from the HP metamorphic complex cluster closely around 340-320 Ma (Xiao et al. 1992; Gao et al. 1995; Gao and Klemd 2003; Wang et al., 2010)

\section{The Gangou ophiolitic mélange}

Along the Toksun-Kumux transect, between the gneissic granites of Central Tianshan and the NTS Carboniferous andesites, a mélange zone composed of several fault-bounded units is exposed. The first unit consists of a clastic and tuffaceous series, similar to the Ordovician flysch but highly schistose ( $\left.S_{1} 110 S 70\right)$; the second unit is a mélange including various altered mafic and ultramafic rocks, cherts, and limestone blocks in a tuffaceous matrix. This ophiolitic mélange (Allen et al. 1993; Ma et al. 1997; Laurent-Charvet 2001; Guo et al. 2002; Shu et al. 2002, 2004) is a part of the accretionary prism associated with the closure of the "Tianshan Paleo-ocean" by southward subduction beneath the Central Tianshan (Laurent-Charvet 2001; Charvet et al. 2001, 2004, 2007; Guo et al. 2002; Shu et al. 2002, 2003; Zhou et al. 2004; Wang et al. 2008). The formation age of this mélange is likely Devonian, as constrained by the presence of Silurian fossils in the limestone blocks. Furthermore, Middle to Late Devonian plutons intrudes the mélange and a Lower Carboniferous unconformity overlies the rocks affected by the first deformation. (XJBGMR 1993; Zhu et al. 2002; Shi et al. 2007). An early slaty cleavage, bearing a rarely preserved stretching lineation trending N280-250, is frequently overprinted by a steep fabric linked with a strike-slip motion, especially near the contacts with granite. The contact between the mélange zone and North Tianshan Carboniferous volcanics rocks is underlined by a ductile-brittle zone, with sigmatype kinematic criteria indicating a top-to-the-north motion (Charvet et al. 2007).

\section{The Central Tianshan microcontinent succession and arc magmatism}

To the south of the (U)HP metamorphic belt, the Haerkeshan Range is made of a Paleozoic succession of carbonates, sandstones and mudstones that was considered as the passive margin of the Tarim plate (Windley et al. 1990; Allen et al. 1993; Carroll et al. 1995, 2001; Wang et al. 1994; Zhou et al. 2001) or a late Permian to Triassic accretionary complex (Xiao et al. 2008). However, subductionrelated granitoids dated at 446-395 Ma by TIMS U-Pb occur south of Gangou-Mishigou (Xu et al. 2006b), north of Kumux (Hopson et al. 1989), north of Baluntai (Yang et al. 2006) and north of Kulehu areas (Fig. 1). Furthermore, early Paleozoic granitic gneisses (Yang et al. 2007) as well as Ordovician-Silurian arc-type volcanic and volcaniclastic rocks are observed in the Bayinbuluk and south of Gangou-Mishigou areas (XJBGMR 1993; Laurent-Charvet 2001; Ma et al. 2006; Charvet et al. 2007).

These Early Paleozoic magmatic and sedimentary rocks stand for the Central Tianshan arc that develops above a Precambrian basement (Wang et al. 2008). The basement rocks exposed in the southernmost part of the Haerkeshan range mainly consist of gneissic granite that formed during 707-931 Ma (zircon U-Pb; Chen et al. 2000b; Zhu 2007). A high ASI value, high LILE and LREE contents, high ${ }^{87} \mathrm{Sr} /{ }^{86} \mathrm{Sr}$ initial ratios $(0.7076 \sim 0.7096)$ and very low $\varepsilon_{\mathrm{Nd}}(\mathrm{T})$ values (-4.4 -7.7) all indicate that this gneissic granite was derived from an ancient continental basement with $\mathrm{Nd}$ mean crustal residence ages of 1.7-1.9 Ga and a long history prior to partial melting (Chen et al. 2000b). Similar granitic gneisses occur also to the north of Kumux and Baluntai areas (Fig. 1). In addition, quartz-schist and marble are exposed and were considered as belonging to the Precambrian basement (Wang et al. 1996).

South of Bayinbuluk or north of Kumux, weakly deformed and unmetamorphosed Early to Middle Carboniferous conglomerate, sandstone and limestone unconformably overlie Early Paleozoic rocks and pre-Carboniferous granitic plutons (Hu et al. 1986, Wang et al. 


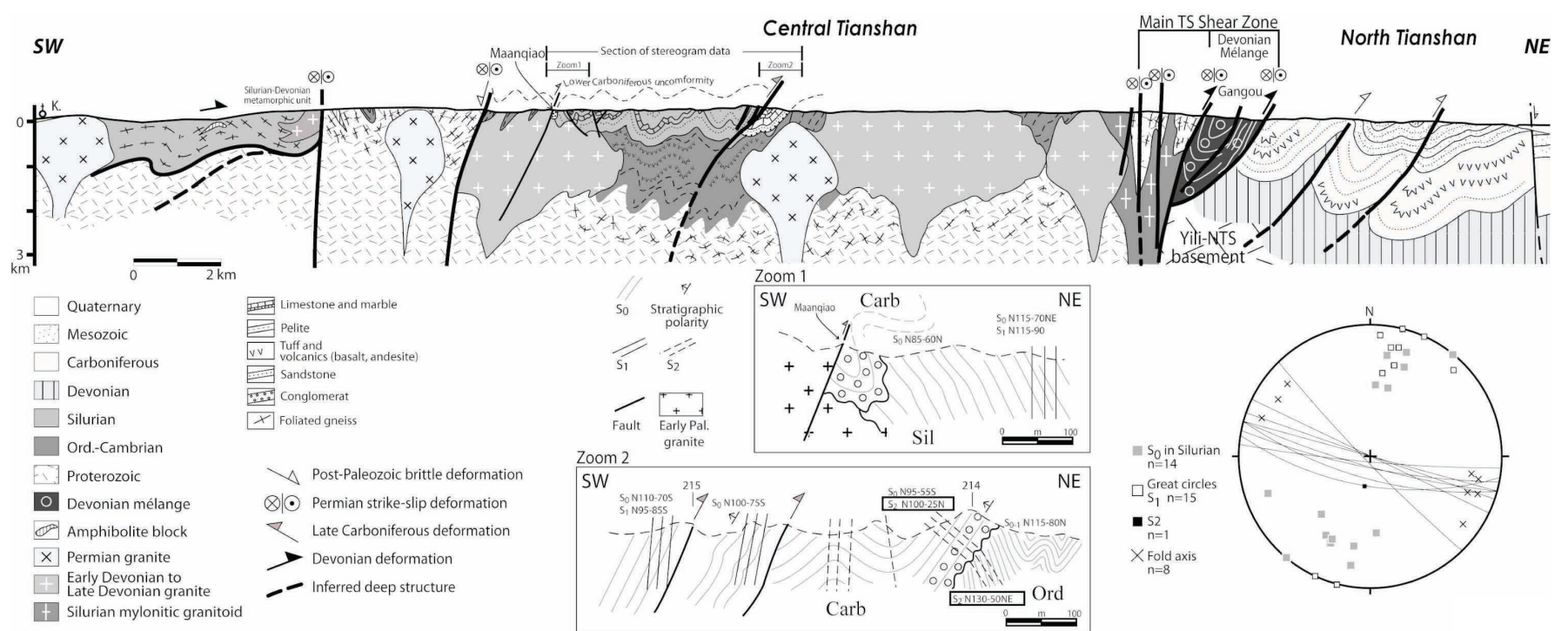

Figure 3. Synthetic cross-section of Central and North Tianshan along the Kumux-Toksun transect (from Charvet et al. 2007).

1994; Zhou et al. 2001; Yang et al. 2006; Charvet et al. 2007; Wang et al. 2008; Fig. 1). Late Devonian to Carboniferous post-collisional granites are also noticed in these areas (Xu et al. 2006a).

\section{The South Tianshan ophiolitic mélange}

In the Southern ranges that form the highest relief of the Tianshan orogen, from Korla to the Kyrgyz border (Fig. 1), the Paleozoic series that represents the cover of the Central Tianshan microcontinent is tectonically overlain by numerous klippes of ophiolitic mélange, such as in Yushugou, Guluogou-Wuwamen, Kulehu, Heiyingshan or Aheqi (Fig. 1). These melanges are composed of serpentinized ultramafic rocks, gabbros, (pillow) basalts, mafic volcanic-clastic rocks, sheeted dyke, chert or siliceous mudstone, limestone and rare high-pressure rocks enclosed in a sheared matrix (Gao et al. 1998; Shu et al. 2002; Charvet et al. 2007; Wang et al. 2008). The geochemical features of the mafic rocks suggest a back-arc basin setting (Ma et al. 1993, 2006; Dong et al. 2005; Long et al. 2006; Zhu 2007). These ophiolite and ophiolitic mélanges were initially assumed to be rooted to the north and emplaced from north to south, onto the Tarim passive margin, after a phase of northward subduction (Windley et al. 1990; Allen et al. 1993; Gao et al. 1998; Xiao et al. 2004; Chen et al. 1999). However, structural studies of the mélange and its tectonic substratum from the Yushugou, Kulehu, and Aheqi areas indicate a top-to-thenorth ductile shearing (Shu et al. 2002; Li et al. 2004; Charvet et al. 2007; Wang et al. 2008). Therefore, these ophiolitic rocks were considered to be originated from the south Tianshan back-arc basin that separated the Central Tianshan microcontinent from the northern margin of Tarim (Charvet et al. 2007; Wang et al. 2008; Lin et al. 2009). The flat-lying foliation and thrust contact are often deformed by south verging folds and high angle thrust faults (Li et al. 2004), but this folding is at least partly due to a Meso-Cenozoic event, since Permian sandstone is affected by the folding (Wang et al. 2008).

The mélanges have been initially assigned to the Silurian (XJBGMR 1993). However, middle Devonian to Early Carboniferous radiolarians in chert olistoliths (Tang et al. 1995; Gao et al. 1998; Liu 2001; Shu et al. 2007; Zhu 2007) argue for a latest Devonian to earliest Carboniferous age, as it is unconformably overlain by an early Carboniferous conglomerate. Recent radiometric dating confirms this assumption. A gabbroic block from Heiyingshan and a diabase from Kulehu (Fig. 1) yield a zircon U-Pb LA-ICPMS age of $392 \pm 5 \mathrm{Ma}$ and SHRIMP age of $425 \pm 8 \mathrm{Ma}$, respectively (Long et al. 2006; Wang et al. in review). In the Kumux area, the granulite block of the Yushugou ophiolitic mélange yields zircon U-Pb SHRIMP ages of 390-392 Ma (Zhou et al. 2004). Therefore, the oceanic lithosphere was, at least partly, created during the Early Devonian and introduced

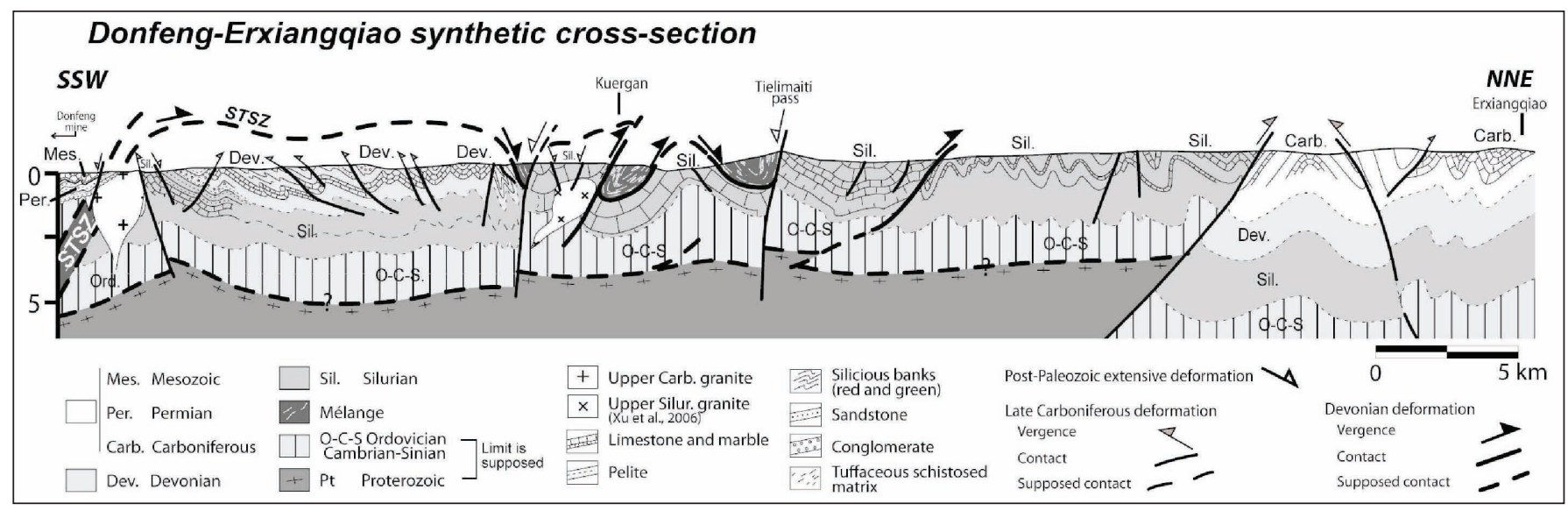

Figure 4. Synthetic cross-section along the Duku road (from Charvet et al. 2007) 
into the mélange together with HP metamorphic rocks (Liu and Qian 2003) around the Devonian-Carboniferous boundary.

\section{The Northern margin of the Tarim block}

The southernmost unit involved in the orogeny of the Tianshan belt corresponds to the northern edge of the Tarim block, exposed in Kuruktag, Korla and Kepingtag. The Tarim block consists of variably deformed and metamorphosed rocks of Archean, Proterozoic to Early Paleozoic ages (XJBGMR 1993; Hu et al. 2000, 2006; Bykadorov et al. 2003; Lu et al. 2008). It has mainly been interpreted as a cratonic block although some different ideas existed (Hsu 1988, 1989). The basement is characterized by Achaean high-grade TTG gneiss and amphibolite and Proterozoic granitic gneiss, which have Nd model ages (TDM) ranging from 3.2 to $2.2 \mathrm{Ga}$ ( $\mathrm{Hu}$ et al., 2000). Neoproterozoic blueschist of ca. $800 \mathrm{Ma}$ age is recognized near Aksu (Nakajima et al., 1991; Liou et al., 1996). Late Neoproterozoic to Ordovician platform sedimentary rocks including limestone and shale form the lower part of the sedimentary cover (Carroll et al., 1995, 2001). The Late Neoproterozoic and Cambrian series may contain intercalations of rift-related volcanic rocks (Xia et al., 2004) and bimodal igneous rocks dated at $820-800 \mathrm{Ma}$ on zircon by LA-ICPMS U-Pb method (Deng et al., 2008). The Silurian overlies the older rocks with a slight unconformity (Carroll et al., 1995), and begins with a conglomerate and includes several polygenetic conglomeratic layers in a flysch-like series. It grades into an olistostrome, with huge olistoliths, to the south of Hongliuhe in Eastern Tianshan, indicating a period of instability (Charvet et al., 2007). Upper Devonian-Lower Carboniferous arc-related plutonic rocks occur at the northern edge of Tarim (Jiang et al., 2001; Zhu et al., 2008), indicating that it acted as an active margin at that time, after being the passive margin of the back-arc basin that separated the Tarim block from the Central Tianshan block during the Silurian-Devonian. Close to the South Tianshan ophiolitic melange, late Carboniferous to early Permian fluvial and marine deposits overlie Sinian to Devonian rocks with an angular unconformity (Carroll et al., 1995; Wang et al., 2008). The Lower Permian strata contain rift-related volcanic and volcaniclastic rocks dated at $275-280 \mathrm{Ma}\left({ }^{40} \mathrm{Ar} /{ }^{39} \mathrm{Ar}\right.$ ages on feldspar and $\mathrm{U}-\mathrm{Pb}$ ages on zircon) and are in turn unconformably overlain by Upper Permian detrital series (Carroll et al., 1995; Chen et al., 1999; Liu et al., 2004).

\section{Acknowledgements}

We thank the office of the Xinjiang 305 Project for co-organizing the field excursion and workshop. We are also grateful to Mr. Gao J., Li J.Y., Ye P., Xu T. and Ms. Guo H., Xie W. for their helpful assistances. Field excursion is financially supported by Chinese National 973 Project no. 2009CB825008 and NSFC (40872142, 90714007).

\section{References}

Allen, M.B., Windley, B.F., and Zhang, C., 1993, Palaeozoic collisional tectonics and magmatism of the Chinese Tien Shan, Central Asia, Tectonophysics, v. 220, no. 1-4, pp. 89-115.

Allen, M.B., Vincent, S.J., and Wheeler, P.J., 1999, Late Cenozoic tectonics of the Kepingtage thrust zone: Interactions of the Tien Shan and Tarim basin, northwest China, Tectonics, v. 18, no. 4, pp. 639-654.
Avouac, J.P., Tapponnier, P., Bai, M., You, H., and Wang G., 1993, Active thrusting and folding along the northern Tien Shan and late Cenozoic rotation of the Tarim relative to Dzungaria and Kazakhstan, Journal of Geophysical Research, v. 98, no. B4, pp. 6755-6804.

Burchfiel, B.C., Brown, E.T., and Deng, Q.D., 1999, Crustal shortening on the Margins of the Tien Shan, Xinjiang, China, International Geology Review, v. 41, pp. 665-700.

Burtman, B.S., 2006. The Tien Shan Early Paleozoic tectonics and geodynamics, Russian Journal of Earth Sciences, v. 8, doi: 10.2205/ 2006ES000202.

Burtman, V S. 1975, Structural geology of Variscan Tien Shan, USSR, American Journal of Science, v. 275A, pp. 157-186

Bykadorov, V.A., Bush, V.A., Fedorenko, O.A., Filippova, I.B., Miletenko, N.V., Puchkov, V.N., Smirnov, A.V., Uzhkenov, B.S., and Volozh, Y.A., 2003, Ordovician- Permian Palaeogeopgraphy of Central Eurasia: development of Palaeozoic petroleum-bearing basins, Journal of Petroleum Geology, v. 26, pp. 325-350.

Cao, R.L., Zhu, S.H., Zhu, X.K., and Guan, Y.B., 1992, Plate and terrane tectonics of Northern Xinjiang. In: Tu, G.Z. (ed.), New Improvement of Solid Geosciences in Northern Xinjiang, Science Press, Beijing, pp. 1126 (in Chinese).

Carroll, A.R., Graham, S.A., Hendrix, M.S., Ying, D., and Zhou, D., 1995, Late Palaeozoic tectonic amalgamation of NW China: sedimentary records of the northern Tarim, northwestern Turpan, and southern Junggar basins, Geological Society of America Bulletin, v. 107, pp. 571-594.

Carroll, A.R., Graham, S.A, Chang, E., and McKnight, C.L., 2001, Sinian through Permian tectonostratigraphic evolution of the northwestern Tarim basin, China, In: Hendrix, M.S., Davis G. (eds) Palaeozoic and Mesozoic tectonic evolution of central and eastern Asia: from continental assembly to intracontinental deformation, Geological Society of America Memoirs, v. 194, pp. 47-69.

Charvet, J., Laurent-Charvet, S., and Shu, L.S., 2001, Paleozoic continental accretions in Central Asia around Junggar Block: new structural and geochronological data, Gondwana Research, v. 4, no. 4, pp. 590-592.

Charvet, J., Laurent-Charvet, S., and Shu, L.S., 2004, Paleozoic geodynamic evolution of Tianshan orogenic belt (NW China): Welding of Tarim and Junggar continental blocks, 32nd IGC -Florence, Symposium G05-09 Tethys reconstruction, abstract, v. 155-3.

Charvet, J., Shu, L., and Laurent-Charvet, S., 2007, Paleozoic structural and geodynamic evolution of eastern Tianshan (NW China): welding of the Tarim and Junggar plates, Episodes, v. 30, pp. 162-186.

Charvet, J., Shu, L.S., Laurent-Charvet, S., Wang, B., Faure, M., Cluzel, D., Chen, Y., and de Jong, K., 2010, Paleozoic tectonic evolution of the Tianshan belt, NW China, Science China Earth Sciences, in press.

Chen, C.M., Lu, H.F., Jia, D., Cai, D.S., and Wu, S.M., 1999, Closing history of the southern Tianshan oceanic basin, western China: an oblique collisional orogeny, Tectonophysics, v. 302, no. 1-2, pp. 23-40.

Chen, J.F., Zhou, T.X., Xie, Z., Zhang, X., and Guo, X.S., 2000a, Formation of positive eNd(T) granitoids from the Alataw Mountains, Xinjiang, China, by mixing and fractional crystallization: implication for Phanernozoic crustal growth, Tectonophysics, v. 328, pp. 53-67.

Chen, Y.B., Hu, A.Q., Zhang, G.X., and Zhang, Q.F., 2000b, Precambrian basement age and characteristics of Southwestern Tianshan: Zircon U$\mathrm{Pb}$ geochronology and Nd-Sr istopic composition, Acta Petrologica Sinica, v. 16, pp. 91-98 (in Chinese with English abstract).

Chen, Y.B., Hu, A.Q., Zhang, G.X., and Zhang, Q.F., 2000c, Zircon U-Pb age of granitic gneiss on Duku highway in western Tianshan of China and its geological implications, Chinese Science Bulletin, v. 45, pp. 649653.

Coleman, R.G., 1989, Continental growth of northwest China, Tectonics, v. 8, pp. 621-635.

de Jong, K., Wang, B., Faure, M., Shu, L., Cluzel, D., Charvet, J., Ruffet, G. and Chen, Y., 2009, New ${ }^{40} \mathrm{Ar} /{ }^{39} \mathrm{Ar}$ age constraints on the Late Palaeozoic tectonic evolution of the western Tianshan (Xinjiang, northwestern China), with emphasis on Permian fluid ingress, International Journal of Earth Sciences, v. 98, pp. 1239-1258. 
Deng, X.L., Shu, L.S., Zhu, W.B., Ma, D.S., and Wang, B., 2008, Precambrian tectonism, magmatism, deformation and geochronology of ignenous rocks in the Xingdi fault zone, Xinjiang, Acta Petrologica Sinica, v. 24, pp. 2800-2808 (in Chinese with English abstract).

Dobretsov, N.L., Coleman, R.G., Liou, J.G., and Maruyama, S., 1987, Blueschist belt in Asia and possible periodicity of blueschist facies metamorphism, Ofioliti, v. 12, pp. 445-456.

Dong, Y.P., Zhou, D.W., Zhang, C.L., Xia, L.Q., Xu, X.Y., and Li, X.M., 2005, Tectonic setting of the Wuwamen ophiolite at the southern margin of Middle Tianshan Belt, Acta Petrologica Sinica, v. 21, no. 1, pp. 37-44 (in Chinese with English abstract).

Gao, J., and Klemd, R., 2003, Formation of HP-LT rocks and their tectonic implications in the western Tianshan Orogen, NW China: geochemical and age constraints, Lithos, v. 66, pp. 1-22.

Gao, J., He, G., Li, M., Xiao, X., Tang, Y., Wang, J., and Zhao, M., 1995, The mineralogy, petrology, metamorphic P-T-D-t trajectory and exhumation mechanism of blueschists, south Tianshan, northwest China, Tectonophysics, v. 250, no. 1-3, pp. 151-168.

Gao, J., Li, M.S., Xiao, X.C., Tan, Y.Q., and He, G.Q., 1998, Paleozoic tectonic evolution of the Tianshan Orogen, northwestern China, Tectonophysics, v. 287 , pp. 213-231.

Gao, J., Klemd, R., Zhang, L., Wang, Z., and Xiao, X., 1999, P-T path of high-pressure/low- temperature rocks and tectonic implications in the western Tianshan Mountains, NW China, Journal of Metamorphic Geology, v. 17, pp. 621-636.

Gao, J., Zhang, L., and Liu, W., 2000, The ${ }^{40} \mathrm{Ar} /{ }^{39} \mathrm{Ar}$ age record of formation and uplift of the blueschists and eclogites in the western Tianshan Mountains, Chinese Science Bulletin, v. 45, pp. 1047-1052.

Gao, J., Long, L., Qian, Q., Huang, D., Su, W., and Klemd, R., 2006, South Tianshan: a Late Paleozoic or a Triassic orogen? Acta Petrologica Sinica, v. 22, pp. 1049-1061 (in Chinese with English abstract).

Gao, J., Long, L., Klemd, R., Qian, Q., Liu, D., Xiong, X., Su, W., Liu, W., Wang, Y., and Yang, F., 2009, Tectonic evolution of the South Tianshan orogen and adjacent regions, NW China: geochemical and age constraints of granitoids rocks, International Journal of Earth Sciences, v. 98, pp. 1221-1238.

Guo, J., Shu, L.S., Charvet, J., and Laurent-Charvet, S., 2002, Geochemical Features of the Two Early Paleozoic Ophiolitic Zones and Volcanic Rocks in the Central-Southern Tianshan Region, Xinjiang, Chinese Journal of Geochemistry, v. 21, no. 4, pp. 308-321.

Han, B.F., Guo, Z.J., Zhang, Z.C., Zheng, L., Chen, J.F., and Song, B., 2010, Age, geochemistry, and tectonic implications of a late Paleozoic stitching pluton in the North Tian Shan suture zone, western China, Geological Society of America Bulletin, v. 122, pp. 627-640.

He, D.F., Chen, X.F., Kuang, J., Yuan, H., Fan, C., Tang, Y., and Wu, X.Z., 2010, Distribution of Carboniferous source rocks and petroleum systems in the Junggar Basin, Petroleum Exploration Development, v. 37, no 4, pp. 397-408.

He, D.F., Chen, X.F., Kuang, J., Zhou, L., Tang, Y. and Liu, D.G., 2008, Development and genetic mechanism of Chepaizi-Mosuowan uplift in Junggar basin, China, Earth Science Frontiers, v. 15, no. 4, pp. 42-55.

Hendrix, M.S., Dumitru, T.A., and Graham, S.A., 1994, Late Oligocene-Early Miocene unroofing in the Chinese Tian Shan: An early effect of the IndiaAsia collision, Geology, v. 22, pp. 487-490.

Hopson, C., Wen, J., Tilton, G., Tang, Y., Zhu, B., and Zhao, M., 1989, Paleozoic plutonism in East Junggar, Bogdashan, and eastern Tianshan, NW China, EOS, Transactions of the American Geophysical Union, v. 70, pp. 1403-1404.

Hsu, K.J., 1988, Relict back-arc basins: Principles of recognition and possible new examples from China. In: Kleinspehn, K.L., Paola, C. (Eds.), New Perspectives in Basin Analysis, Springer, New York, pp. 245-263.

Hsu, K.J., 1989, Origin of sedimentary basins in China. In: Hsu, K.J., Zhu, X. (Eds.), Chinese Sedimentary Basins, Elsevier, Amsterdam, pp. 207227.

Hu, A.Q., Zhang, Z.G., Liu, J.Y., Peng, J.H., Zhang, J.B., Zhao, D.J., Yang, S.Z., and Zhou, W., 1986, U-Pb age and evolution of Precambrian metamorphic rocks of the middle Tianshan uplift zone, eastern Tianshan, China, Geochimica, v. 1, pp. 23-35 (in Chinese with English abstract).

Hu, A.Q., Jahn, B.M., and Zhang, G.X., 2000, Crustal evolution and Phanerozoic crustal growth in northern Xinjiang: Nd isotopic evidence. Part I: Isotopic characterization of basement rocks, Tectonophysics, v. 328 , no. 1-2, pp. 15-51.

Hu, A.Q., Zhang, G.X., and Chen, Y.B., 2006, Isotope geochronology and geochemistry for major geological events of continental crustal evolution of Xinjiang, China, Beijing: Geological Publishing House, 427pp (in Chinese with English abstract).

Jahn, B.M., 2004, The Central Asia Orogenic Belt and growth of the continental crust in the Phanerozoic. In: Malpas, J., Fletcher, C.J.N., Ali, J.R., Aitchison, J.C. (eds.), Aspects of the tectonic evolution of China, Geological Society of London Special Publication, v. 226, pp. 73-100.

Jahn, B.M., Griffin, W.L., and Windley, B.F., 2000, Continental growth in the Phanerozoic; evidence from Central Asia, Tectonophysics, no. 1-2, v. 328 , pp. vii-x.

Jahn, B.M., Windley, B.F., Natal'in, B., and Dobretsov, N., 2004, Phanerozoic Continental Growth in Central Asia, Journal of Asian Earth Sciences, v. 23, pp. 599-603.

Ji, Y.L., Zhou, Y., Kuang, J., Wan, L., Zhang, R., and Lu, C.H., 2010, The formation and evolution of Chepaizi-Mosuowan paleo-uplift and its control on the distributions of sedimentary facies in the Junggar Basin, Science China Earth Sciences, v. 53, no. 6, pp. 818-831, doi: $10.1007 /$ s11430-010-3068-2.

Jiang, C.Y., Mu, Y.M., Zhao, and X. N., 2001, Petrology and geochemistry of the intrusion belt along the northern active margin of the Tarim plate, Regional Geology of China, v. 20, pp. 158-163 (in Chinese with English abstract).

Klemd, R., Brocker, M., Hacker, B., Gao, J., Gans, P., and Wemmer, K., 2005, New age constraints on the metamorphic evolution of the highpressure/low temperature belt in the Western Tianshan Mountains, NW China, The Journal of Geology, v. 113, pp. 157-168.

Konopelko, D., Biske, G., Seltmann, R., Eklund, O., and Belyatsky, B., 2007, Hercynian post-collisional A-type granites of the Kokshaal Range, Southern Tien Shan, Kyrgyzstan, Lithos, v. 97, pp. 140-160.

Kröner, A., Hegner, E., Lehmann, B., Heinhorst, J., Wingate, M.T.D., Liu, D.Y., and Ermelov, P., 2008, Palaeozoic arc magmatism in the Central Asian Orogenic Belt of Kazakhstan: SHRIMP zircon ages and wholerock Nd isotopic systematics, Journal of Asian Earth Sciences, v. 32, pp. 118-130.

Kröner, A., Windley, B.F., Badarch, G., Tomurtogoo, O., Hegner, E., Jahn, B.M., Gruschka, S., Khain, E.V., Demoux, A., and Wingate, M.T.D., 2007, Accretionary growth and crust formation in the Central Asian Orogenic Belt and comparison with the Arabian-Nubian shield. In: Hatcher R.D., Carlson, M.P., McBride, J.H., Martínez, C.J.R. (eds.), 4D Framework of Continental Crust, Geological Society of America Memoirs, v. 200, pp. 181-209.

Laurent-Charvet, S., 2001, Accrétions continentales en Asie centro-orientale : évolution géodynamique etstructurale du Tianshan et du Junggar oriental (nord-ouest Chine) au Paléozoïque, Ph.D Dissertation, University of Orléans, Orléans, France, 312pp.

Laurent-Charvet S., Charvet, J., Shu, L.S., Ma, R.S., and Lu, H.F., 2002. Palaeozoic late collisional strike-slip deformations in Tianshan and Altay, eastern Xinjiang, NW China, Terra Nova, v.14, no. 4, pp. 249256.

Laurent-Charvet, S., Charvet, J., Monié, P., and Shu, L.S., 2003, Late Paleozoic strike-slip shear zones in eastern Central Asia (NW China): new structural and geochronological data, Tectonics, v. 22, No. 2, pp. 1099-1101.

Li, J.Y., Xiao, W.J., and Wang, K.Z., 2003, Neoproterozoic-Paleozoic tectonostratigraphic framework of Eastern Xinjiang, NW China. In: Mao, J.W., Goldfarb, R., Seltmann, R., Wang, D.H., Xiao, W.J., Hart, C. (eds.), Tectonic evolution and metallogeny of the Chinese Altay and Tianshan, IGCP 473 workshop, Urumqi. International Association on the Genesis of Ore Deposits (IAGOD), CERCAMS. London Natural History Museum, pp. 31-74 
Li, S.H., and Du, Q., 1994, The ophiolites in Motogou-Gurt of Wusu County, Xinjiang Geology, v. 1, pp. 265-271 (in Chinese with English abstract).

Li, X.D., Xiao, W.J., and Zhou, Z.L., 2004, ${ }^{40} \mathrm{Ar} /{ }^{39} \mathrm{Ar}$ age determination on the Late Devonian tectonic event along the southern margin of the South Tianshan Mountains and its significance, Acta Geologica Sinica, v. 20, pp. 691-696 (in Chinese with English abstract).

Li, Z.W., Roecker, S., Li, Z., Wei, B., Wang, H., Schelochkov, G., and Bragin, V., 2009, Tomographic image of the crust and upper mantle beneath the western Tien Shan from the MANAS broadband deployment: Possible evidence for lithospheric delamination, Tectonophysics, v. 477, pp. 4957.

Lin, W., Faure, M., Shi, Y., Wang, Q., and Li, Z., 2009, Paleozoic Tectonics of Southwestern Chinese Tianshan: New insights from a structural study of the high-pressure/ low-temperature metamorphic belt, International Journal of Earth Sciences, v. 98, pp. 1259-1274.

Liou, J.G., Graham, S.A., and Maruyama, S., 1996, Characteristics and tectonic significance of the Late Proterozoic Aksu blueschists and diabasic dikes, Northwest Xinjiang, China, International Geology Review, v. 38, pp. 228-244.

Liu, B., and Qian, Y., 2003, The geological characteristics and fluid evolution in the three high-pressure metamorphic belts of eastern Tianshan, Acta Petrologica Sinica, v. 19, pp. 283-296 (in Chinese with English abstract).

Liu, S.W., Guo, Z.J., and Zhang, Z.C., 2004, Nature of the Precambrian metamorphic blocks in the eastern segment of Central Tianshan: constraints from geochronology and $\mathrm{Nd}$ isotopic geochemistry, Science in China (Series D), v. 47, pp. 1085-1094.

Liu, Y., 2001, Early Carboniferous radiolarian fauna from Heyingshan south of Tianshan Mountains of China and its geological significance, Acta Geologica Sinica, v. 75, pp. 101-109.

Long, L.L., Gao, J., Xiong, X.M., and Qian, Q., 2006, The geochemical characteristics and the age of the Kule Lake ophiolite in the southern Tianshan, Acta Petrologica Sinica, v. 22, pp. 65-73 (in Chinese with English abstract).

Lu, S., Li, H., Zhang, C., and Niu, G., 2008, Geological and geochronological evidence for the Precambrian evolution of the Tarim craton and surrounding continental fragments, Precambrian Research, v. 160, pp. 94-107.

Ma, R.S., Shu, L.S., and Sun, Y., 1997, Tectonic evolution and metallogenic of eastern Tianshan Mountains, Geological Publishing House, Beijing, 202pp (in Chinese with English abstract).

Ma, Z.P., Xia, L.Q., Xu, X.Y., Li, X.M., Xia, Z.C., and Wang, L.S., 2006, The tectonic setting and implication of volcanic-magmatic complex from the Upper-Silurian Bayinbuluke Formation, Southern Tianshan, Journal of Jilin University, v. 36, pp. 736-743 (in Chinese with English abstract).

Mikolaichuk, A.V., Kotov, V.V., and Kuzikov, S.I., 1995, Structural position of the Malyi Naryn metamorphic complex as related to the problem of the boundary between the North and Median Tian Shan, Geotectonics (English translation), v. 29, pp. 157-166.

Mikolaichuk, A.V., Kurenkov, S.A., Degtyarev, K.E., and Rubtsov, V.I., 1997, Northern Tien Shan: main stages of geodynamic evolution in the late Precambrian-early Paleozoic. Geotectonics (English translation), v. 31 (6), pp. 445-462.

Nakajima, T, Maruyama, S., and Uchiumi, S., 1991, The age of the oldest blueschist of the world-the Aksu Group of Western China, Nature, v. 346, pp. 263-265.

Nelson, M.R., McCaffrey, R., and Molnar, P., 1987, Source parameters for eleven earthquakes in the Tien Shan, central Asia: Determined by $\mathrm{P}$ and SH waveform inversion, Journal of Geophysical Research, v. 92, pp. 12629-12648.

Qian, Q., Gao, J., and Klemd, R., 2009, Early Paleozoic tectonic evolution of the Chinese South Tianshan orogen: constraints from SHRIMP zircon $\mathrm{U}-\mathrm{Pb}$ geochronology and geochemistry of basaltic and dioritic rocks from Xiate, NW China, International Journal of Earth Sciences, v. 98, pp. 551-569.

Qin, K.Z., Sun, S., and Li, J.L., 2002, Palaeozoic epithermal Au and $\mathrm{Cu}$ deposits in North Xinjiang, China: Epochs, features, tectonic linkage and exploration significance, Resource Geology, v. 52, pp. 29-300.

Qin, K.Z., 2000, Metallogeneses in Relation to the Central Asian-style Orogeny in Northern Xinjiang, Postdoctoral Report, Institute of Geology and Geophysics, Chinese Academy of Sciences, 194pp (in Chinese with English abstract).

Sengör, A.M.C., Natal'in, B.A., and Burtman, V.S., 1993, Evolution of the Altaid tectonic collage Paleozoic crustal growth in Eurasia, Nature, v. 364, pp. 299-307.

Sengör, A.M.C., and Natal'In, B.A., 1996, Palaeotectonics of Asia: Fragments of a synthesis. In: Yin, A, Harrison, TM (eds.), Tectonic Evolution of Asia, Cambridge Univ, Press, Cambridge, United Kingdom, pp. 486640.

Shi, Y.R., Liu, D.Y., and Zhang, Q., 2007, SHRIMP zircon U-Pb dating of the Gangou granitoids, Central Tianshan Mountains, Northwest China and tectonic significances, Chinese Science Bulletin, v. 52, pp. 15071516.

Shu, L.S., Charvet, J., Guo, L.Z., Lu, H.F., and Laurent-Charvet, S., 1999, A large-scale Paleozoic dextral ductile strike-slip zone: the AqqikkudugWeiya zone along the northern margin of the Central Tianshan belt, Xinjiang, NW China, Acta Geologica Sinica, v. 73, pp. 148-162.

Shu, L.S., Lu, H.F., Charvet, J., Laurent-Charvet, S., and Yin, D.H., 2000, Paleozoic accretionary terranes in Northern Tianshan, NW China, Chinese Journal of Geochemistry, v. 19, pp. 193-202.

Shu, L.S., Charvet, J., and Lu, H.F., 2002, Paleozoic accretion-collision events and kinematics of ductile deformation in the central-southern Tianshan Belt, China, Acta Geologica Sinica, v. 76, pp. 308-323.

Shu, L.S., Wang, B., Yang, F., Lu, H.F., Charvet, J., and Laurent-Charvet, S., 2003, Polyphase tectonic events and Mesozoic-Cenozoic basin-range coupling in the Chinese Tianshan belt, Acta Geologica Sinica, v. 7, pp. 457-467.

Shu, L.S., Wang, B., Zhu, W.B., Guo, Z.J., Charvet, J. and Zhang, Y., 2010, Timing of initiation of extension in the Tianshan, geochemical and geochronological analyses of bimodal volcanism and olistostrome in the Bogda Shan (NW China), International Journal of Earth Sciences, doi 10.1007/s00531-010-0575-5.

Sobel, E.R., and Dumitru, T.A., 1997, Thrusting exhumation around the margins of the western Tarim basin during the India-Asia collision, Journal of Geophysical Research, v. 102, pp. 5043-5063.

Tagiri, M., Yano, T., Bakirov, A., Nakajima, T., and Uchiumi, S., 1995, Mineral parageneses metamorphic P-T paths of ultrahigh-pressure eclogites from Kyrghyzstan Tien-Shan, Island Arc, v. 4, pp. 280-292.

Tang, Y., Gao, J., Zhang, M., and Wang, J., 1995, The ophiolite blueschist in the southwestern Tianshan orogenic belt Xinjiang, NW China, Geological publishing house, Beijing, 133pp (in Chinese with English abstract).

Tapponnier, P., Peltzer, G., and Armijo, R., 1986, On the mechanics of the collision between India and Asia . In: Coward MP, Ries AC (eds.), Collision Tectonics, Geological Society of London Special Publication, v. 19 , pp. 115-157

Volkova, N.I., and Budanov, V.I., 1999, Geochemical discrimination of metabasalt rocks of the Fan-Karategin transitional blueschist/greenschist belt, South Tianshan, Tajikistan: Seamount volcanism accretionary tectonics, Lithos, v. 47, pp. 201-216.

Wang, B., 2006, Paleozoic geodynamic evolution of Yili Block in West Chinese Tianshan, $\mathrm{PhD}$ thesis, Nanjing University-Orleans University, NanjingOrleans, 153pp.

Wang, B., Faure, M., Cluzel, D., Shu, L.S., Charvet, J., Meffre, S., and Ma Q., 2006, Late Paleozoic tectonic evolution of the northern West Chinese Tianshan Belt, Geodinamica Acta, v. 19, pp. 227-237.

Wang, B., Shu, L.S., Cluzel, D., Faure, M., and Charvet, J., 2007a, Geochemical Constraints on Carboniferous Volcanic rocks of Yili Block (Xinjiang, NW China): implication on tectonic evolution of Western Tianshan, Journal of Asian Earth Sciences, v. 29, pp. 148-159.

Wang, B., Chen, Y., Zhan, S., Shu, L.S., Faure, M., Cluzel, D., Charvet, J., and Laurent-Charvet, S., 2007b, Primary Carboniferous and Permian paleomagnetic results from the Yili Block (NW China) and their 
implications on the geodynamic evolution of Chinese Tianshan Belt, Earth and Planetary Science Letters, v. 263, pp. 288-308.

Wang, B., Shu, L.S., Faure, M., Cluzel, D., and Charvet, J., 2007c, Paleozoic tectonism and magmatism of Kekesu-Qiongkushitai section in southwestern Chinese Tianshan and their constraints on the age of the orogeny, Acta Petrologica Sinica, v. 23, pp. 1354-1368 (in Chinese with English abstract).

Wang, B., Shu, L.S., Cluzel, D., Faure, M., and Charvet, J., 2007d, Geochronological and geochemical studies on the Borohoro plutons, north of Yili, NW Tianshan and their tectonic implication, Acta Petrologica Sinica, v. 23(8), pp. 1885-1900 (in Chinese with English abstract).

Wang, B., Faure, M., Shu, L.S., Cluzel, D., Charvet, J., De Jong, K., and Chen, Y., 2008, Paleozoic tectonic evolution of the Yili Block, Western Chinese Tianshan, Bulletin de la Societé Géologique de France, v. 179, pp. 483-490.

Wang, B., Cluzel, D., Shu, L.S., Faure, M., Charvet, J., Chen, Y., Meffre, S., and de Jong, K., 2009, Evolution of calc-alkaline to alkaline magmatism through Carboniferous convergence to Permian transcurrent tectonics, western Chinese Tianshan. International Journal of Earth Sciences, v. 98, no. 6, pp. 1275-1298.

Wang, B., Shu, L.S., Faure, M., Jahn, B.M., Cluzel, D., Charvet, J., Chung, S.L., and Meffre, S., 2010a, Paleozoic tectonics of the southern Tianshan: New insights from structural, chronological and geochemical studies of the Heiyingshan ophiolitic mélange (NW China), Tectonophysics, doi:10.1016/j.tecto.2010.11.004.

Wang, B., Faure, M., Shu, L.S., de Jong, K., Charvet, J., Cluzel, D., Jahn, B.M., Chen, Y., and Ruffet, G., 2010b, Structural and geochronological study of High-Pressure metamorphic rocks in the Kekesu section (Northwestern China): implications for the late Paleozoic tectonics of the southern Tianshan, The Journal of Geology, v. 118, pp. 59-77.

Wang, B.Y., Lang, Z.J., Li, X.D., Qu, X., Li, T., Huang, C., and Cui, X., 1994, Comprehensive survey of geological sections in the west Tianshan of Xinjiang, China, Science Publishing House, Beijing, 202pp.

Wang, C.Y., Yang, Z.E., Luo, H., and Mooney, W.D., 2004, Crustal structure of the northern margin of the eastern Tien Shan, China, and its tectonic implications for the 1906 M 7.7 Manas earthquake. Earth and Planetary Science Letters, v. 223, no. 1-2, pp. 187-202.

Wang, S.J., Hu, S.B., Li, T.J., Wang, J.Y. and Zhao, W.Z., 2000, Terrestrial heat flow in Junggar basin, northwest China, Chinese Science Bulletin, v. 45 , no 19 , pp. $1808-1813$.

Wang, X.C., He, G.Q., and Li, M.S., 1996, A discussion on the time of the Kuergan micro-massif in South Tianshan, Journal of Chengdu University of Technology, v. 23, pp. 90-95 (in Chinese with English abstract).

Wang, Y., Li, J.Y., and Sun, G.H., 2008, Postcollisional Eastward Extrusion and Tectonic Exhumation along the Eastern Tianshan Orogen, Central Asia: Constraints from Dextral Strike-Slip Motion and ${ }^{40} \mathrm{Ar} /{ }^{39} \mathrm{Ar}$ Geochronological Evidence, The Journal of Geology, v. 116, pp. 599618.

Wartes, M.A., Carroll, A.R., and Greene, T.J., 2002, Permian sedimentary record of the Turpan-Hami basin and adjacent regions, northwest China: constraints on postamalgamation tectonic evolution, Geological Society of America Bulletin, v. 114, pp. 131-152.

Windley, B.F., Allen, M., Zhang, C., Zhao, Z., and Wang, G., 1990, Paleozoic accretion Cenozoic redeformation of the Chinese Tien Shan Range, central Asia, Geology, v. 18, pp. 128-131.

Windley, B.F., Alexeiev, D., Xiao, W., Kroener, A., and Badarch, G., 2007, Tectonic models for accretion of the Central Asian orogenic belt, Journal of the Geological Society London, v. 164, pp. 31-47.

Wu, J., and Liu, C., 1989, Geological features of Bayingol ophiolite complexes in North Tien Shan, Xinjiang, Acta Petrologica Sinica, v. 2, pp. 76-87 (in Chinese with English abstract).

Xia, L.Q., Xu, X.Y., Xia, Z.C., Li, X.M., Ma, Z.P., and Wang, L.S., 2004, Petrogenesis of Carboniferous rift-related volcanic rocks in the Tianshan, northwestern China, Geological Society of America Bulletin, v. 116, pp. 419-433.

Xia, L.Q., Zhang, G., Xia, Z., Xu, X.Y., Dong, Y.P., and Li, X.M., 2002,
Constraints on the timing of opening and closing of the Tianshan Paleozoic oceanic basin: evidence from Sinian and Carboniferous volcanic rocks, Geological Bulletin of China, v. 21, pp. 55-62 (in Chinese with English abstract).

Xiao, W.J., Zhang, L.C., Qin, K.Z., Sun, S., and Li, J., 2004, Paleozoic accretionary collisional Tectonics of the Eastern Tianshan (China): Implications for the Continental growth of Central Asia, American Journal of Science, v. 304, pp. 370-395.

Xiao, W.J., Han, C.M., Yuan, C., Sun, M., Lin, S.F., Chen, H., Li, Z., Li, J., and Sun, S., 2008, Middle Cambrian to Permian subduction-related accretionary orogenesis of Northern Xinjiang, NW China: Implications for the tectonic evolution of central Asia, Journal of Asian Earth Sciences, v. 32 , pp. 102-117.

Xiao, X.C., Tang, Y.Q., Feng, Y.M., Zhu, B., Li, J., and Zhao, M., 1992, The tectonic evolution of North Xinjiang its adjacent regions, Geol Publ House, Beijing, 190pp (in Chinese).

XJBGMR-Xinjiang, Bureau of Geology and Mineral Resources, 1993, Regional geology of Xinjiang Uygur Autonomy Region, Geol Mem Geol Pub House, Beijing, v. 32, 841pp.

Xu, X.Y., Ma, Z.P., and Xia, L.Q., 2005, SHRIMP dating of plagiogranite from Bayingou ophiolite in the northern Tianshan Mountains, Geological Review, v. 51, pp. 523-527 (in Chinese with English abstract).

Xu, X.Y., Li, X.M., and Ma, Z.P., 2006a, LA-ICPMS zircon U-Pb dating of gabbro from the Bayingou Ophiolite in the northern Tianshan Mountains, Acta Geologica Sinica, v. 80, pp. 1168-1176 (in Chinese with English abstract).

Xu, X.Y., Ma, Z.P., Xia, Z.C., Xia, L.Q., Li, X.M., and Wang, L.S., 2006b, TIMS U-Pb isotopic dating and geochemical characteristics of Palaeozoic granitic rocks from the Middle-Western section of Tianshan, Northwest Geology, v. 39, pp. 50-75 (in Chinese with English abstract).

Xu, X.Y., Wang, H.L., Ma, G.L., Li, P., Chen, Y.L., and Li, T., 2010, Geochronology and Hf isotope characteristics of the Paleozoic granite in Nalati area, West Tianshan Mountains, Acta Petrologica et Mineralogica, v. 29, no. 6, pp. 691-706 (in Chinese with English abstract).

Yang, T.N., Li, J.Y., Sun, G.H., and Wang, Y.B., 2006, Earlier Devonian active continental arc in Central Tianshan: evidence of geochemical analyses Zircon SHRIMP dating on mylonitized granitic rock, Acta Petrologica Sinica, v. 22, pp. 41-48 (In Chinese with English abstract).

Yang, T.N., Wang, Y., and Li, J.Y., 2007, Vertical and horizontal strain partitioning of the Central Tianshan (NW China): Evidence from structures and ${ }^{40} \mathrm{Ar} /{ }^{39} \mathrm{Ar}$ geochronology, Journal of Structural Geology, v. 29 , pp. 1605-1621.

Yang, X.K., Tao, H.X., Luo, G.C., and Ji, J.S., 1996, Basic features of plate tectonics in Eastern Tianshan of China, Xinjiang Geology, v. 14, pp. 221-227 (in Chinese with English abstract).

Yang, X.K., Cheng, H.B., Ji, J.S., Luo, G.C., and Tao, H.X., 2000, Analysis on gold and copper ore-forming setting with ore-forming system of Eastern Tianshan, Journal of Xi' an Engineering University, v. 22, pp. 714 (in Chinese with English abstract).

Yang, X.K., Su, C.Q., Cheng, H., Zhang, H.J., Yan, H.Q., Li, X.F., and Liu, J.Q., 2006, Discovery of the Permian volcanic rocks in the Bingdaban-Houxia, Tianshan Mountains, and its geological significance, Geological Bulletin of China, v. 25, pp. 969-976 (in Chinese with English abstract).

Yin, A., and Nie, S., 1996, A Phanerozoic palinspastic reconstruction of China its neighboring regions, In: Yin, A., Harrison, T.M. (eds)., Tectonic Evolution of Asia, Cambridge University Press, Cambridge, United Kingdom, pp. 442-485.

Yin, A., Nie, S., Craig, P. and Harrison, T.M., 1998, Late Cenozoic tectonic evolution of the southern Chinese Tianshan, Tectonics, v. 17, pp. 1-27.

Zhai, W., Sun, X.M., Gao, J., He, X.P., Liang, J.L., Miao, L.C., and Wu, Y.L., 2006, SHRIMP dating of zircons from volcanic host rocks of Dahalajunshan Formation in Axi gold deposit, Xinjiang, China, its geological implications, Acta Petrologica Sinica, v. 22, pp. 1399-1404 (in Chinese with English abstract).

Zhang, L.F., Ai, Y.L., Li, X.P., Rubatto, D., Song, B., Williams, S., Song, 
S.G., Ellis, D., and Liou, J.G., 2007, Triassic collision of western Tianshan orogenic belt, China: Evidence from SHRIMP U-Pb dating of zircon from HP/UHP eclogitic rocks, Lithos, v. 96, pp. 266-280.

Zhou, D., Graham, S.A., Chang, E.Z., Wang, B.Y., and Hacker, B., 2001, Paleozoic tectonic amalgamation of the Chinese Tianshan: Evidence from a transect along the Dushanzi-Kuqa highway. In: Hendrix, M.S., Davis, G.A. (eds.), Paleozoic Mesozoic tectonic evolution of central Asia: from continental assembly to intracontinental deformation, Boulder, Colorado, Geological Society of America Memoirs, v. 194, pp. 23-46.

Zhou, D.W., Su, L., and Jian, P., 2004, Zircon U-Pb SHRIMP ages of Yushugou ophiolitic terrane in Southern Tianshan and their tectonic implications, Chinese Science Bulletin, v. 49, pp. 1415-1419.

Zhu, B.Q., Feng, Y.M., and Yang, J.L., 2002, Discovery of ophiolitic mélange and Silurian foreland basin at Gangou of Tokxun, Xinjiang and their tectonic significance, Xinjiang Geology, v. 20, pp. 326-330 (in Chinese with English abstract).
Zhu, Y.F., Zhang, L.F., Gu, L.B., Guo, X., and Zhou, J., 2005, The zircon SHRIMP chronology trace element geochemistry of the Carboniferous volcanic rocks in western Tianshan Mountains, Chinese Science Bulletin, v. 50, pp. 2201-2212.

Zhu, Y.F., Zhou, J., and Guo, X., 2006, Petrology Sr-Nd isotopic geochemistry of the Carboniferous volcanic rocks in the western Tianshan Mountains, NW China, Acta Petrologica Sinica, v. 22, pp. 1341-1350 (in Chinese with English abstract).

Zhu, Z.X., 2007, The geological components and tectonic evolution of South Tianshan, Xinjiang, PhD Dissertation, Chinese Academy of Geological Sciences, Beijing, 210pp.

Zhu, Z.X., Li, J.Y., Dong, L.H., Wang, K.Z., Liu, G.Z., Li, Y.P., and Liu, Z.T., 2008, Age determination and geological significance of Devonian granitic intrusions in Seriyakeyilake region, northern margin of Tarim basin, Xinjiang, Acta Petrologica Sinica, v. 24, pp. 971-976 (in Chinese with English abstract).

\section{PART II: FIELD DESCRIPTIONS}

\section{Day 1. Baiyanggou section (Southern Bogda): Early Permian rift}

This short section presents a series of magmatic and sedimentary rocks: Carboniferous limestone olistoliths, Permian volcanic breccia, pillow basalt, deep water chert, flysch and mafic dykes (Fig. 6).

Stop 1-1: $43^{\circ} 38.368^{\prime} \mathrm{N}$ and $87^{\circ} 58.150^{\prime} E$, Milestone $10-11$

Intrusive contact between the gabbro dykes and the host Early Permian flysch.

Stop 1-2: $43^{\circ} 40.922^{\prime} \mathrm{N}$ and $88^{\circ} 03.129^{\prime} \mathrm{E}, 200 \mathrm{~m}$ North of a limestone

Boundary between Permian pillow basalt and the overlying sediments (siliceous mudstone and siltstone).

Stop 1-3: $43^{\circ} 41.081^{\prime} \mathrm{N}$ and $88^{\circ} 02.950^{\prime} \mathrm{E}, 100 \mathrm{~m}$ further north

Contact between the pillow lava and the underlying flysch-like greywacke, tuff and volcanic breccia. Alkaline rhyolite was interlayered in the volcanic breccia and was dated at $294 \pm 5 \mathrm{Ma}$ (zircon U-Pb; Shu et al., 2005).

Stop 1-4: $43^{\circ} 41.154^{\prime} \mathrm{N}$ and $88^{\circ} 02.902^{\prime} \mathrm{E}$

Olistostrome made of olistoliths of Carboniferous limestone with variable size and tuff matrix. The olistostrome is intruded by alkaline gabbroic dykes of $297 \pm 5 \mathrm{Ma}$ (zircon U-Pb, Shu et al., 2010).

The Baiyanggou section is interpreted as an Early Permian riftsequence, which might have been deposited in a rift basin formed after the late Carboniferous tectonics.

\section{Hougou section: North Tianshan accretionary complex} overlain by Early Permian terrigeneous and volcanic rocks

SE of Urumqi, on the road subparallel to the G312 highway, starting from the Dabancheng Ancient Town, the Hougou section exposes Carboniferous schistose mudstone, olistostrome and broken formation, Carboniferous granite, Early Permian continental sedimentary rocks, volcanic and volcano-sedimentary rocks. An Early Permian unconformity upon the Carboniferous rocks can be observed.
Stop 1-5: $43^{\circ} 18.628^{\prime} N$ and $88^{\circ} 21.182^{\prime} E$, between milestones $93 \mathrm{~km}$ and $94 \mathrm{~km}$ of the Road G314, close to a bridge of the highway G312.

Carboniferous olistostrome made of blocks of limestone, chert and volcanics, and muddy matrix. Well developed cleavage and quartz veins indicate sub-N-S shortening. Initial bedding is difficult to distinguish.

Stop 1-6: $43^{\circ} 15.953^{\prime} N$ and $88^{\circ} 21.580^{\prime} E$, between milestones 99 and $100 \mathrm{~km}$ of the Road G314.

Broken formation composed of red siliceous mudstone, greenish chert and siliceous tuff, with black matrix of mudstone. The olistostrome and broken formation correspond to the Carboniferous fore-arc accretionary prism of the North Tianshan.

Stop 1-7 (optional): $43^{\circ} 11.894^{\prime} \mathrm{N}$ and $88^{\circ} 28.209^{\prime} \mathrm{E}$, at $112.8 \mathrm{~km}$ of the Road G314.

Carboniferous greyish medium to coarse-grained granite intrudes Carboniferous tuff, in which contact metamorphism occurred. Thin pink granitic dikes in turn intrude the grayish granite.

Stop 1-8: $43^{\circ} 11.705^{\prime} N$ and $88^{\circ} 28.359^{\prime}$ E, between milestones 113 and $114 \mathrm{~km}$ of the Road G314.

Unconformable contact between Carboniferous (tuff and granite) and Early Permian. Northern side is the Carboniferous siliceous tuffs, southern side is Early Permian red-yellowish conglomerate with big pebbles of volcanics, chert, mudstone and granite. Rhyolitic and andesitic rocks are interlayered in the conglomerate. The present contact zone and bedding of Permian are sub-vertical.

Further south, interlayers of conglomerate, sandstone and rhyolite or rhyolitic tuff occur regularly, occurrence of tuff breccia and conglomerate with huge volcanic fragments suggests sedimentation very close to the erupting center. Basic dikes intrude in the Permian rocks.

Stop 1-9 (optional): $43^{\circ} 09.717^{\prime} N$ and $88^{\circ} 29.262^{\prime} E$, between milestones 117 and $118 \mathrm{~km}$ of the Road G314.

Early Permian fluviatile coloured conglomerate, and red sandstone showing sedimentary rythms. On the western side of highway G312, 


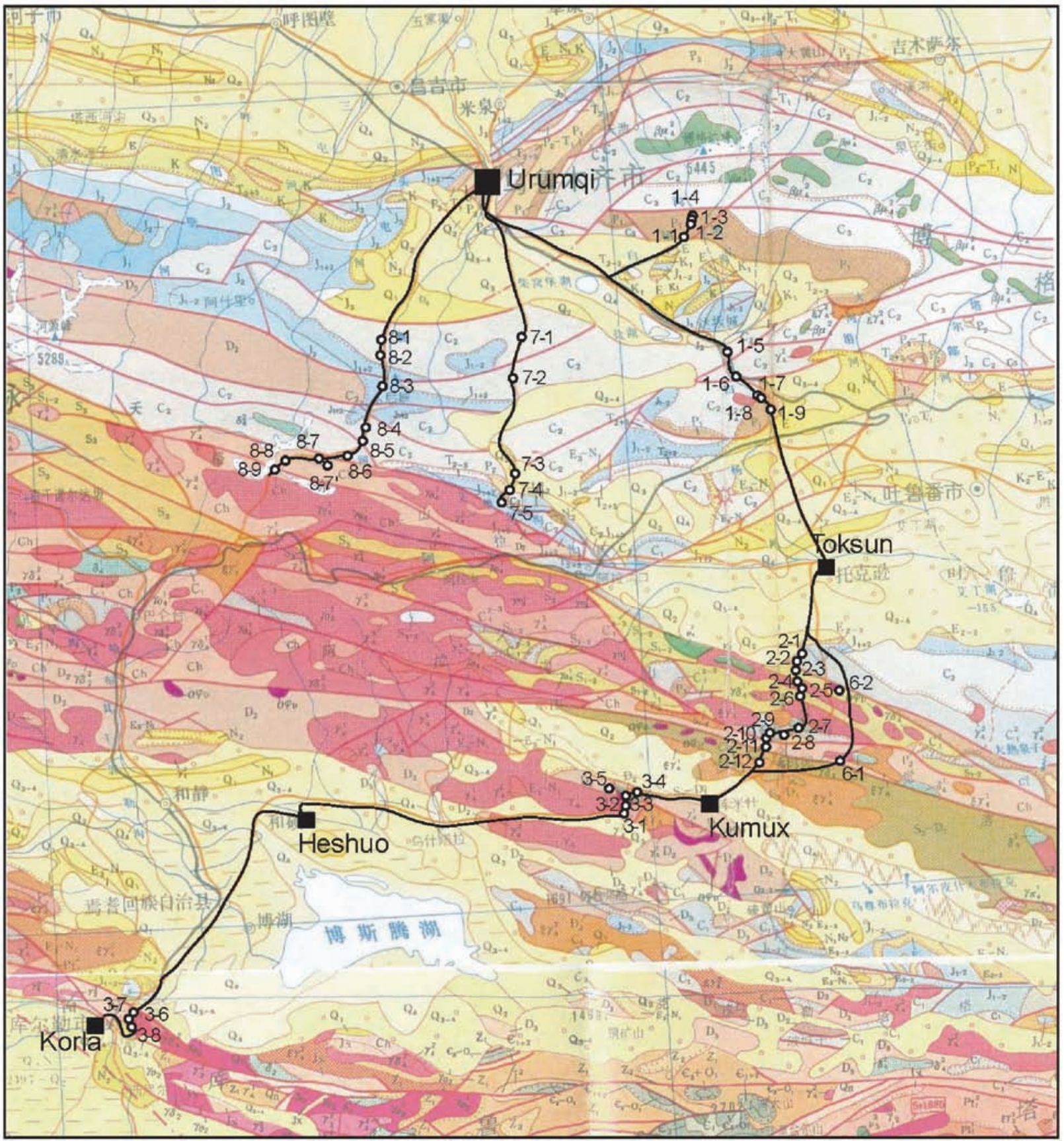

Figure 5. Geological map and the circuit for Days 1, 2, 3, 6, 7 and 8.

the panorama shows Early Permian rocks unconformably overlain by Late Triassic and Jurassic rocks.

Day 2. Gangou section: Early Paleozoic ophiolitic mélange, arc magmatic rocks and Late Paleozoic unconformity Suture zone between Central Tianshan and Yili-North Tianshan blocks

South of Toksun, along Highway G314 (direction Toksun to Kumux, i.e., North to South), this section exposes the North Tianshan volcanic arc, Gangou ophiolitic mélange, Ordovician to Silurian schistose volcanic and volcaniclastic rocks, Early Paleozoic arc-type granitoids, the Carboniferous unconformity, and Proterozoic metamorphic basement rocks (Figs. 5 \& 7).
Stop 2-1: $42^{\circ} 35.340^{\prime} N$ and $88^{\circ} 32.758^{\prime} E$, Milestone 184-185, at the parking near $184.5^{\text {th }} \mathrm{km}$ of the new road

Tuff and volcanic rocks of Early Carboniferous age, basalt and red andesite. These rocks are considered as the north Tianshan arc formed by the southward subduction of the North Tianshan oceanic basin beneath the Yili-North Tianshan block during the Late Paleozoic (Charvet et al. 2007).

Stop 2-2: $42^{\circ} 32.673^{\prime} N$ and $88^{\circ} 31.836^{\prime} E$, Milestone 191 , by a small bridge

Highly deformed Early Carboniferous volcano-sedimentary rocks related to the Main Tianshan Shear Zone. Steeply south-dipping foliation, subhorizontal lineation and asymmetric clasts in the mylonitized tuff indicate a dextral shearing. This shear zone separates 


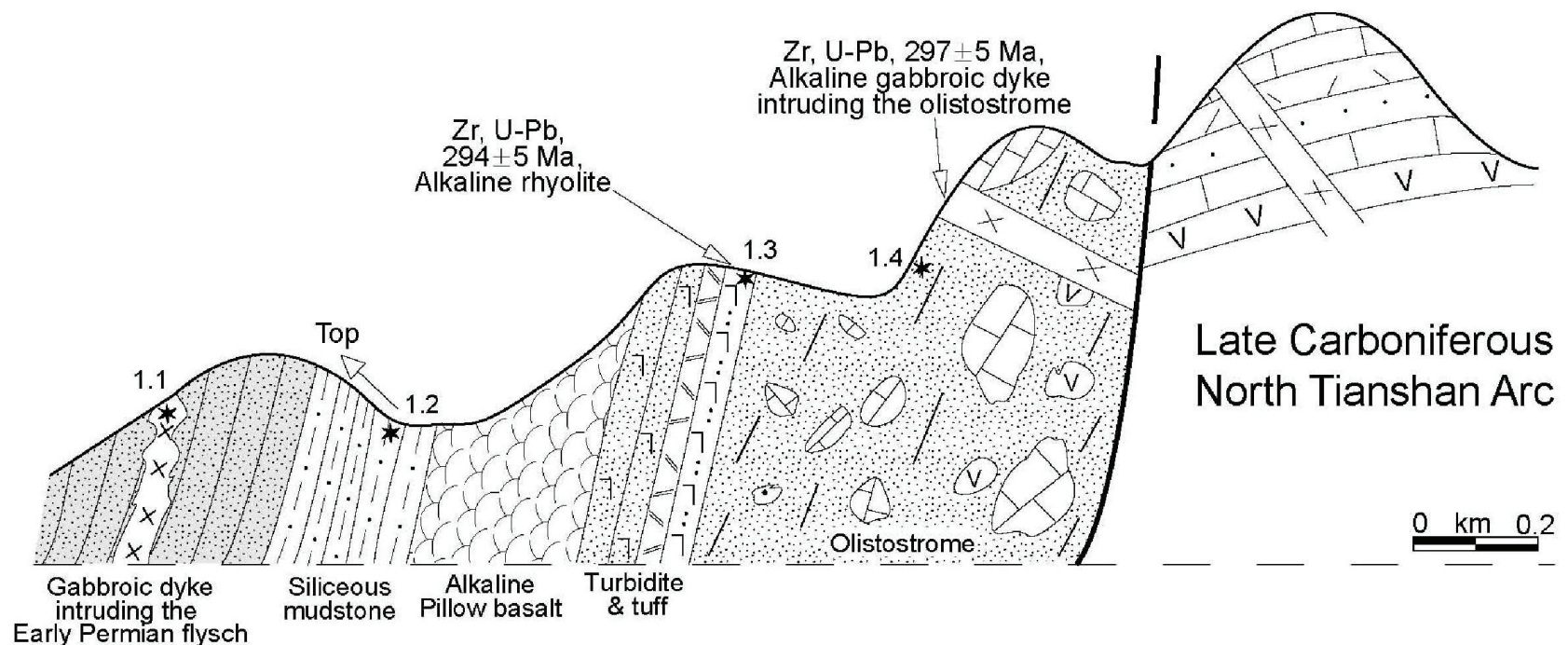

Figure 6. Cross section of Baiyanggou, south of Bogda Mountain.

the Early Carboniferous arc volcanic rocks to the north from the Gangou ophiolitic mélange and Early Paleozoic volcanic arc series to the south.

Stop 2-3: $42^{\circ} 32.238^{\prime} N$ and $88^{\circ} 31.872^{\prime} E$, Milestone 192-193, by a bridge near the $192.6^{\text {th }} \mathrm{km}$

Gangou ophiolitic mélange consists of blocks of metatuff, greenstone, chert, and the matrix made of greywacke. The mélange zone of ca. $30 \mathrm{~m}$ wide strikes SEE-ward (N120). Reddish granite intrudes in the mélange zone.

\section{Stop 2-4: $42^{\circ} 31.406^{\prime} N$ and $88^{\circ} 31.761^{\prime}$ E, Milestone 194}

Orthogneiss derived from a porphyritic K-granite dated at $428 \pm$ $10 \mathrm{Ma}$ by U-Pb method on zircon (Shi et al. 2007). Mylonitic zones with subvertical foliation and a low angle stretching lineation exhibit a dextral sense of shear. The orthogneiss is intruded by undeformed doleritic dykes on unknown age. This plutonic body is interpreted as related to a Silurian magmatic arc, and the ductile deformation is due to the Permian strike-slip tectonics.
Stop 2-5: 42³0.840’ $N$ and 88³1.098’ E, Milestone 196

Slightly oriented fine-grained granite with xenoliths. Developing a visible contact metamorphism in the host-rock of OrdovicianSilurian meta-volcanoclastic rocks, this undeformed post-tectonic granite is dated at $368 \pm 9 \mathrm{Ma}$ (Shi et al. 2007).

Stop 2-6: $42^{\circ} 28.500^{\prime} N$ and $88^{\circ} 31.462^{\prime}$ E, Milestone $201.7 \mathrm{~km}$

Schistose Silurian mafic volcanoclastic rocks belonging to the Central Tianshan arc. A contact metamorphism with andalusite can be also observed. This rock is also exposed at the $200.6^{\text {th }} \mathrm{km}$ (GPS: $42^{\circ} 29.104^{\prime} \mathrm{N}$ and $88^{\circ} 31.741^{\prime}$ E).

Stop 2-7: $42^{\circ} 23.835^{\prime} N$ and $88^{\circ} 31.285^{\prime}$ E, Milestone $212.4 \mathrm{~km}$ of the new road

Unconformity of Early Carboniferous conglomerate above the Ordovician metatuffs. Early Carboniferous conglomerate is overlain conformably by crinoidal limestone of Early to Middle Carboniferous. Both formations are affected by a $\mathrm{S}_{2}$ cleavage, associated with south verging folds.
N

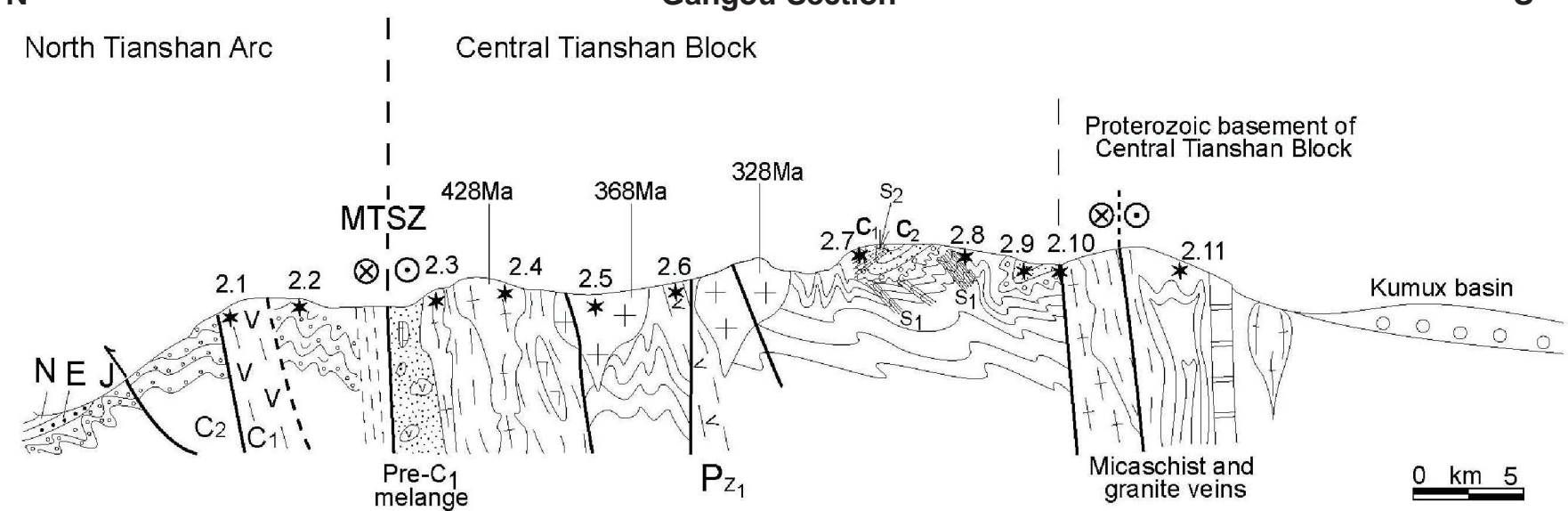

Figure 7. Schematic cross section of the Gangou-Kumux transect. 

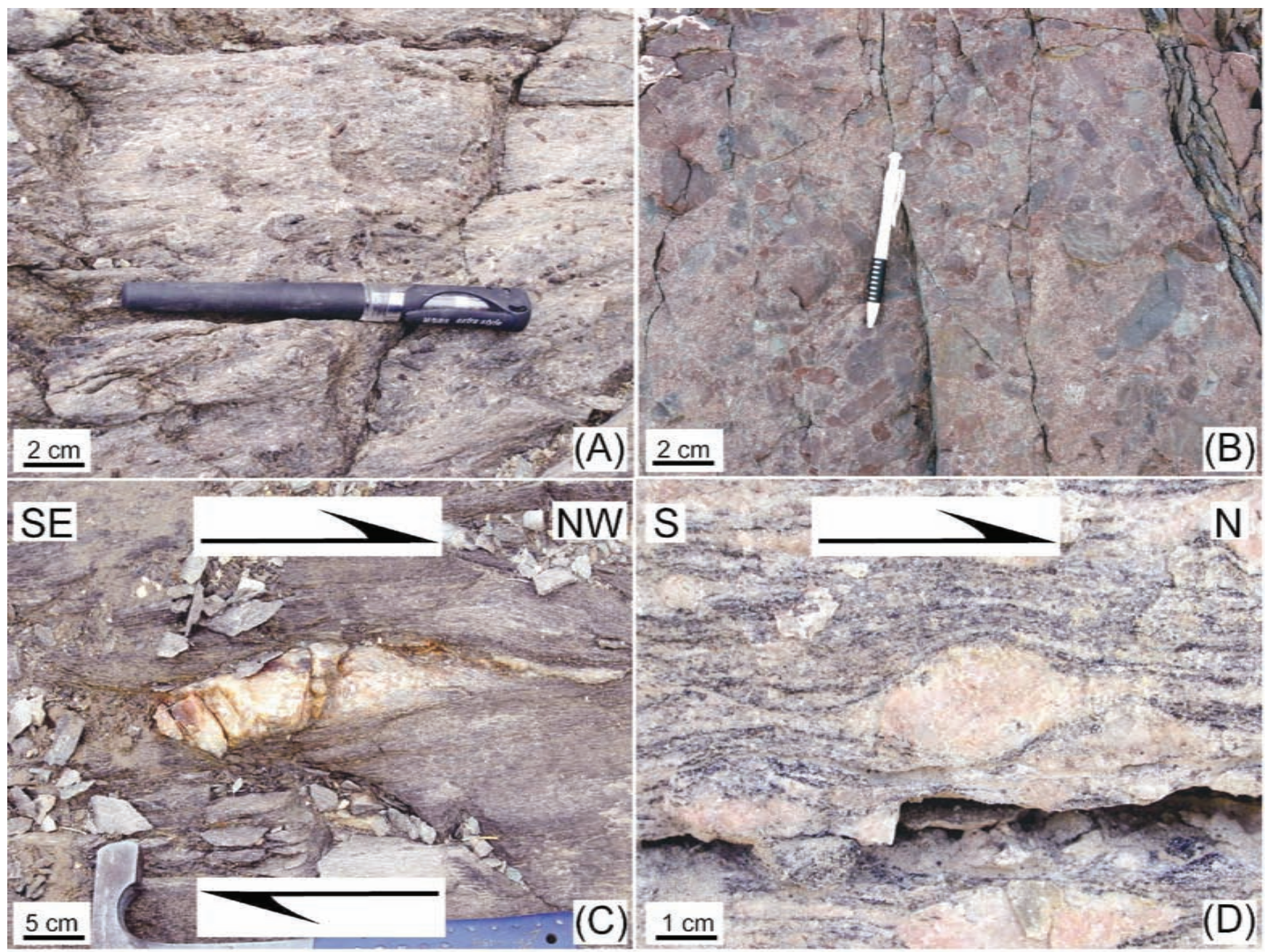

Figure 8. Field pictures related to the cross section between Toksun and Kumux. A. Garnet micaschist which is considered as the Proterozoic basement of Central Tianshan; B. Conglomerate of Early Carboniferous (Ma'Anqiao group); C. Quartz, vein, which indicated dextral sense of shear, was considered as the Proterozoic basement of Central Tianshan; D. Augen gneiss indicating top-to-the-North sense of shear.

Stop 2-8: $42^{\circ} 22.479^{\prime} \mathrm{N}$ and $88^{\circ} 28.618^{\prime}$ E, Milestone $217.4^{\text {th }} \mathrm{km}$ of the new road

Silurian limestone and flysch, asymmetric tight folds and flatlying shear zone indicate a north-directed movement.

Stop 2-9: $42^{\circ} 22.101^{\prime} N$ and $88^{\circ} 27.975^{\prime}$ E, at Ma'anqiao, Milestone $218.7^{\text {th }} \mathrm{km}$

Overturned Lower Carboniferous non-schistosed red conglomerate $\left(\mathrm{C}_{1} \mathrm{Ma}\right.$ 'anqiao group) overlying Silurian fossiliferous flysch affected by a south-dipping cleavage. Granite pebbles are common in the conglomerate.

Stop 2-10 (optional): $42^{\circ} 21.342^{\prime} N$ and $88^{\circ} 26.796^{\prime}$ E, Milestone 220 221 of the new road

Fault contact between Proterozoic gneiss and Lower Paleozoic (Ordovician?) schists. The supposed basement rocks of the Central Tianshan are highly deformed by the Sangshuyuanzi Fault showing N120-striking vertical foliation and sub-horizontal lineation, kinematic criteria indicate a dextral sense of shear. Nevertheless, the orthogneiss near the Marble Mine which shows asymmetrical augen $\mathrm{K}$-feldspar, sigma-type quartz and S-C composite foliation, indicates a sinistral sense of shear (foliation 120NE75; lineation 110/10).
Stop 2-11: $42^{\circ} 19.610^{\prime} N$ and $88^{\circ} 24.803^{\prime}$ E, near Sangshuyuanzi, milestone 227

Mylonitic marble and biotite garnet micaschist, paragneiss of Xingxingxia Group considered as the Proterozoic basement of Central Tianshan. These rocks exhibit a vertical foliation and a subhorizontal mineral and stretching lineation. The related ductile deformation indicates a dextral sense of shear, corresponding to the eastward extension of the Nalati Fault. Hornblende, biotite and K-feldspar yield ${ }^{40} \mathrm{Ar} /{ }^{39} \mathrm{Ar}$ ages around $350 \mathrm{Ma}$ and $260 \mathrm{Ma}$, respectively (Yin and Nie 1996). Centimeter-scale blue hydrothermal kyanite develops close to granite-pegmatite veins. Monazite $\mathrm{U}-\mathrm{Th}-\mathrm{Pb}$ dating on the kyanitestaurolite -garnet-bearing schist of Xingxingxia group yield an age of $\sim 343 \mathrm{Ma}$ that is interpreted as a mixture of older age at ca. $355 \mathrm{Ma}$ and younger age of ca. $323 \mathrm{Ma}$, which could be related with a HP metamorphism and subsequent retrogression, respectively; Much younger age of $282 \pm 9 \mathrm{Ma}$ was also well defined and considered as related to shear deformation (Li et al., 2008).

Stop 2-12 (optional): $42^{\circ} 16^{\prime} 57^{\prime \prime} N$ and $88^{\circ} 21.08^{\prime} E$, Milestone 232.8 th $\mathrm{km}$ of the new road, on the west of the road (This site is now inaccessible because of the wire fence)

Mylonitic syn-kinematic K-granite with subhorizontal stretching 


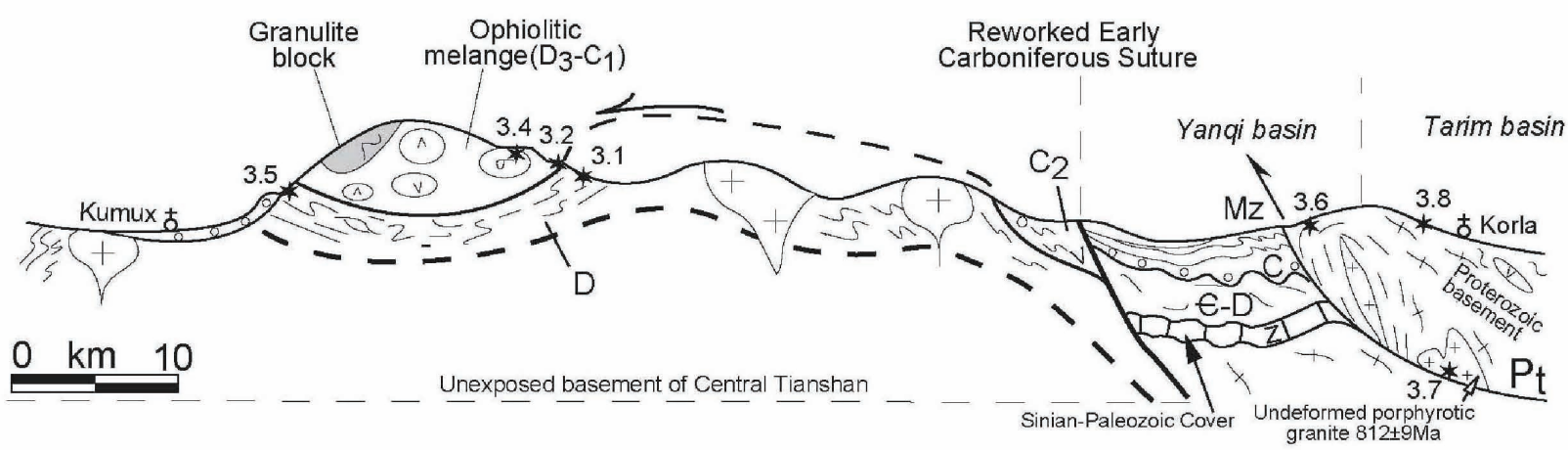

Figure 9. Schematic cross section of theYushugou ophiolitic mélange zone.

lineation. Sigmoidal K-feldspar shows dextral sense of shear. Kgranite was dated at $254 \pm 4$ Ma by zircon U-Pb ICPMS method (Wang et al. 2009).

\section{Day 3. Yushugou section: Pre-Carboniferous ophiolite, granulite-facies meta-mafic rocks, top-to-the-north kinematics, Tarim basement}

To the west of Kumux Town along the highway G314, the South Tianshan ophiolitic zone crops out in the Yushugou area where serpentinized peridotite and granulite can be observed (Fig. 9). The Yushugou ophiolitic body and the neighboring ones, such as the Tonghuashan-Liuhuangshan mafic and ultramafic bodies are considered as the ophiolitic mélanges of the Chinese South Tianshan (Ma et al., 1993; Guo et al., 1993; Charvet et al., 2007).

Stop 3-1: $42^{\circ} 14.001^{\prime} N$ and $87^{\circ} 55.026^{\prime} E$, west side of a bridge at the crossing with the poor road going to an asbestos mine

Devonian meta-flysch with marble blocks. NE-dipping foliation and NE-plunging lineation are well developed, intrafolial asymmetric tight folds and numerous kinematic criteria indicating a top-to-thenorth shearing along a N10-N40 lineation.

Stop 3-2: $42^{\circ} 14.264^{\prime} \mathrm{N} 87^{\circ} 55.161^{\prime} \mathrm{E}$, ca.350 $\mathrm{m}$ to the north of stop 4-1

Basal contact of the ophiolitic mélange with the highly deformed Silurian-Devonian flysch, the mélange is composed of blocks of serpentinite, gabbro, basalt, chert and marble. In the matrix of the mélange, greywacke and pelitic rocks were ductilely deformed with a north-dipping foliation and N30-50 striking lineation. In the XZ section, S-C fabrics, sigmoidal clasts and drag-folds show a top-tothe-north sense of shear.

Stop 3-3 (optional): just before exit the Yushugou near the stop 4-4

Contact between the granulite unit and the ophiolitic mélange unit. Blocks of basalt and gabbro developed in serpentinite matrix.

Stop 3-4: $42^{\circ} 15.879^{\prime} N$ and $87^{\circ} 54.918^{\prime} E$, at the $N E$ side of the exit of the Yushugou valley

Coarse-grained mafic granulite enclosed in a serpentinite matrix. The protolith of the granulite is considered as a mafic rock (Shu et al. 2004; Zhou et al. 2004). Granulite yielded zircon U-Pb SHRIMP ages of $390 \pm 11 \mathrm{Ma}$ and $392 \pm 7 \mathrm{Ma}$ (Zhou et al. 2004), and Caamphibole from the granulite yielded ${ }^{40} \mathrm{Ar} /{ }^{39} \mathrm{Ar}$ ages of $368 \pm 5 \mathrm{Ma}$ and $360 \pm 10 \mathrm{Ma}$, and grt+pl+ilm+WR Sm-Nd isochron age of $310 \pm 10 \mathrm{Ma}$ (Wang et al. 2003). Zircon U-Pb ages were interpreted by Zhou et al.(2004) as the time of peak metamorphism under granulite-facies, but Wang RS et al. (2003) considered the amphibole ${ }^{40} \mathrm{Ar} /{ }^{39} \mathrm{Ar}$ ages at $370-360$ as the peak metamorphism, and the Sm-Nd age of $310 \mathrm{Ma}$ as the retrogression.

Stop 3-5 (optional): Milestone 280 of the old road (this site is now along the new highway and there is no parking)

Roof pendant of the mélange within a granite body supposed to be Carboniferous or Permian in age, with contact metamorphism.

Stop 3-5': 42 $15.926^{\prime} \mathrm{N}$ and $87^{\circ} 53.570^{\prime} \mathrm{E}$, at the 274.2th $\mathrm{km}$ of the new highway (no parking)

Early Carboniferous highly deformed meta-flysch with boudinaged quartz veins, intrafolial tight folds. The foliation trends N160E and contains a N45E striking stretching lineation. Asymmetric kinematic indicators show a top-to-the-NE shearing.

\section{The second part of this day deals with the basement of the} Tarim Block exposed along the Highway north of Korla

Stop 3-6: $41^{\circ} 48.654^{\prime} \mathrm{N}$ and $86^{\circ} 14.816^{\prime} \mathrm{E}$, at the $6.77 \mathrm{~km}$

Retrogressed biotite amphibolite with folded and foliated granitic veins. The amphibolite foliation is oriented N80 S50 contains a N160E mineral lineation. The granitic veins yield zircons dated at $2.8 \mathrm{Ga}$, 1.9 Ga, $1 \mathrm{Ga}$, and $0.8 \mathrm{Ga}$ (Deng et al., 2008).

\section{Stop 3-7: $41^{\circ} 48.068$ and $86^{\circ} 13.927$ at the $678^{\text {th }} \mathrm{km}$}

Biotite micaschist with nearly parallel granitic veins. The $120 \mathrm{E}$ S60 foliation is cross-cut by magmatically oriented porphyritic granite with biotite clots and K-feldspar megacrysts. This plutonic rock yield zircons dated at $812 \pm 9$ Ma by LA-ICPMS method (Shu et al., unpublished data).

Stop 3-8: $41^{\circ} 47.546$ and $86^{\circ} 13.616$ at the $680^{\text {th }} \mathrm{km}$

Garnet amphibolite, marble, garnet-biotite micaschist, quartzite, and calc-silicate. The foliation is still dipping southward (N90 S80). The metamorphic series is intruded by 1 to $5 \mathrm{~m}$-thick garnet-biotite granitoids veins. Locally, meter-sized boudins of garnet amphibolite can be observed. 


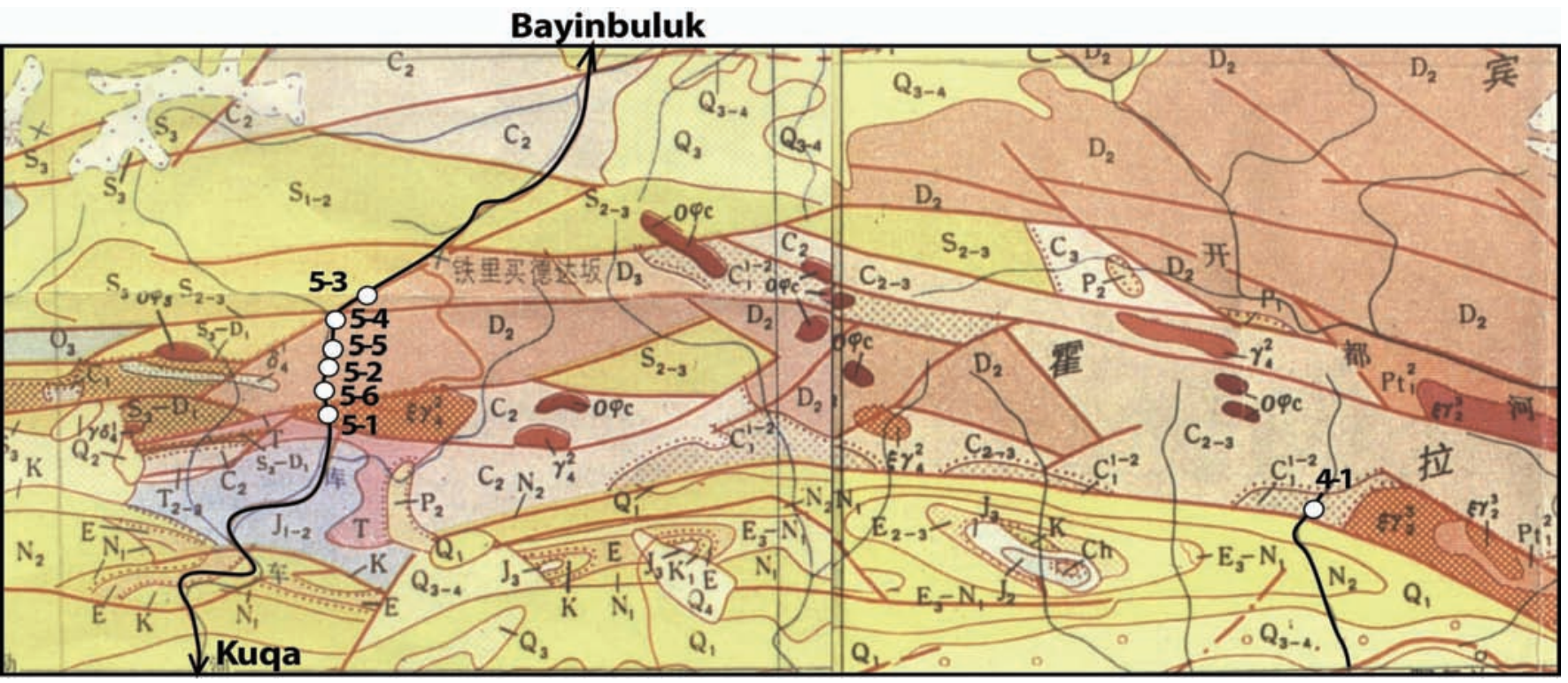

Figure 10. Geological map and the circuit for Days 4 and 5 in the central part of South Chinese Tianshan.

Day 4. Cedaya section: Carboniferous limestone of Northern Tarim

Stop 4: North of Highway G314, between Korla and Kuqa.

In this section, we shall observe a coarse-grained sandstone and mudstone formation with limestone layers containing coral fossils of Carboniferous age. This series is considered as a mass flow supplied from the northern part of the Tarim block.

Day 5. Du-Ku road section: Pre- $\mathrm{C}_{2}$ ophiolitic mélange, sedimentary cover of the Central Tianshan block, and polyphase deformation

North of Kuqa city, road G217, along the banks of the Kuqa River. This section allows us to observe the sedimentary cover of the Central Tianshan block, and the South Tianshan ophiolitic mélange overthrust to the north (Fig. 12).

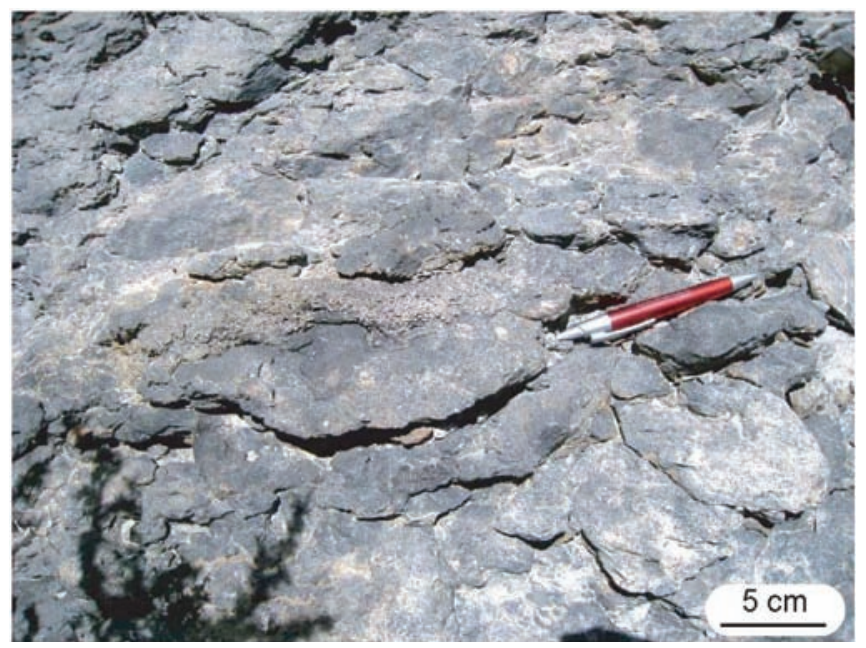

Figure 11. Terrigeneous formation with limestone layers containing Carboniferous coral.
Stop 5-1: 42 $17^{\prime} 28^{\prime \prime} N$ and $83^{\circ} 16^{\prime} 39^{\prime \prime}$ E, near Milestone 985 of Road G217. Immediately north of the Shengli coal mine and Triassic red sediments

Diorite, granodiorite and red granite intrude mica-quartz schist of unknown age. Red granite includes diorite enclaves. Diorite pluton yielded zircon U-Pb SHRIMP age of $387 \pm 8 \mathrm{Ma}$ (Zhu et al. 2008). Since these granitoids show arc geochemical affinities (Zhu et al. 2008), they are interpreted as the magmatic arc formed upon the northern margin of the Tarim Block. On the road, the arc-type granitoids are in fault contact with Upper Permian conglomerate, but an unconformity is also recognized nearby. Pebbles of granitic rocks, chert, sandstone and basalt can be identified in the Upper Permian conglomerate.

Stop 5-2: 42 $23^{\prime} 54^{\prime \prime} N$ and $83^{\circ} 16^{\prime} 21^{\prime \prime} E$, Milestone 968 of Road G217

Contact between the Early-Middle Devonian limestone and the schistose sandstone, which forms the matrix of the Kulehu melange. North-vergent folds and faults develop in the limestone overthrusting to the north above the schist. At Milestone 967, the andalusite-bearing micaschist yielded a muscovite ${ }^{40} \mathrm{Ar} /{ }^{39} \mathrm{Ar}$ plateau age of $368 \pm 1 \mathrm{Ma}$ (Li et al. 2004).

Stop 5-3: Kulehu ophiolitic mélange with various rock types

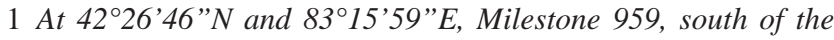
Dalaoba ("Big dragon lake"). Pillow lava blocks included in the limestone and schistose matrix;

2 At $42^{\circ} 25^{\prime} 50^{\prime \prime} N$ and $83^{\circ} 15^{\prime} 29^{\prime \prime}$, near Milestone 963.1, sheared calcareous flysch and limestone (sometime marble) with disrupted bedding showing north-vergent folds;

3 At $42^{\circ} 26^{\prime} 24^{\prime \prime} N$ and $83^{\circ} 15^{\prime} 38^{\prime \prime} E$, around Milestone 961.8, radiolarian chert and siliceous mudstone with remarkable cleavage indicating north-directed shearing. Late Devonian to Early Carboniferous radiolarians were found from the chert (Tang et al. 1995; Gao et al. 1998; Zhu 2007);

4 At $42^{\circ} 26^{\prime} 29^{\prime \prime} N$ and $83^{\circ} 15^{\prime} 49^{\prime \prime}$, around Milestone 963.1, block of basalts and gabbro that have geochemical features of N-MORB, 


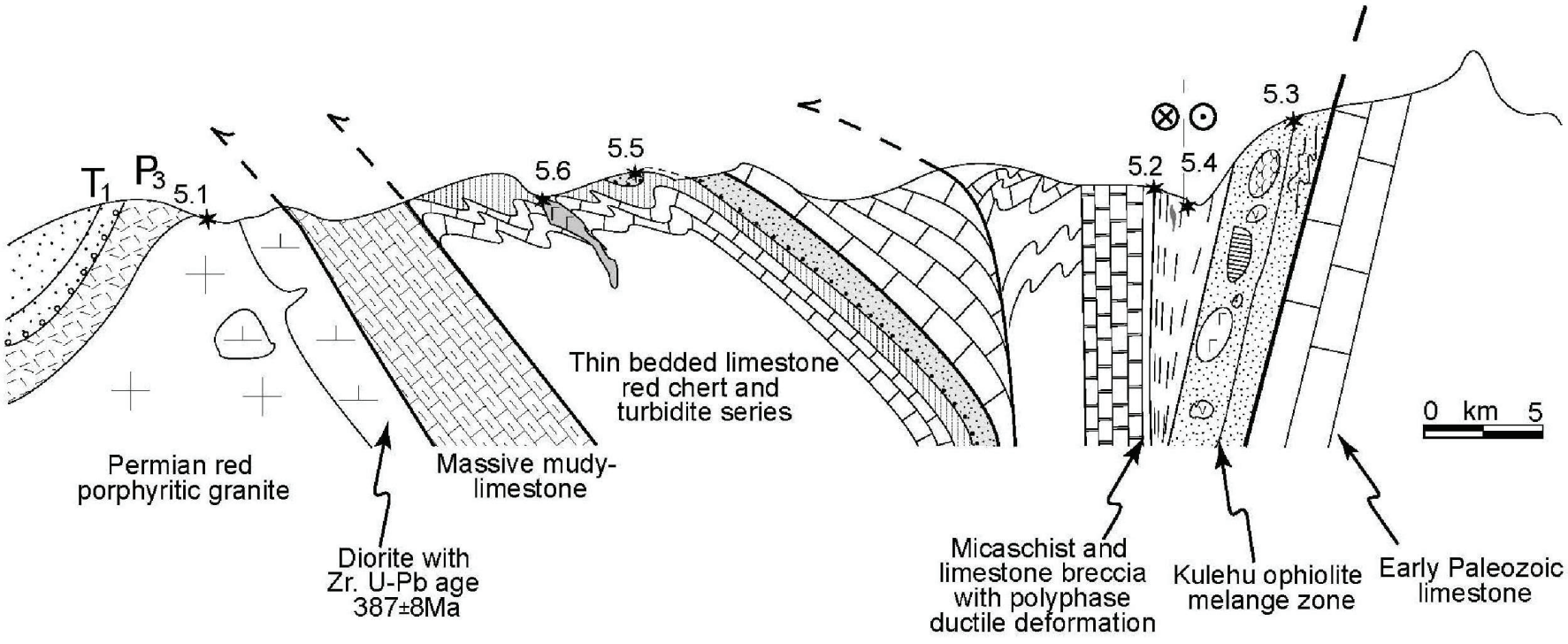

Figure 12. Schematic cross section of the southern segment of the Du-Ku Road.

gabbro yielded zircon SHRIMP U-Pb age of $425 \pm 8 \mathrm{Ma}$ (Long et al. 2006).

The Kulehu ophiolitic mélange is interpreted as a north-directed klippe overlying the limestone-red chert series. This mélange exhibits the same lithological and structural features than the Yushugou mélange klippe. Both are considered as parts of the South Tianshan mélange that tectonically overlies the central Tianshan Block.

Stop 5-4: $42^{\circ} 25.911^{\prime} N$ and $83^{\circ} 14.969^{\prime} E$, South of Korgan village

Andalusite-cordierite micaschist showing a well developed subvertical foliation and subhorizontal lineation. These metamorphic minerals and planar-linear structural fabric are related to the Permian dextral strike-slip shearing. An early, steeply dipping, (N-S striking) stretching lineation can also be observed in some places. To the south, recrystallized Silurian limestone, with locally limestone breccia, exhibits also a steeply dipping stretching lineation. This ductile deformation is related to the emplacement of the Kulehu mélange klippe.

\section{Stop 5-5: $42^{\circ} 22.770^{\prime} N$ and $83^{\circ} 15.877^{\prime} E$}

Turbidite with alternations of coarse- to medium-grained sandstone and mudstone, disrupted sandstone beds, intraformational conglomerate. Load casts at the base of sandstone beds indicate that this north-dipping series is overturned. Bedding-cleavage relationships show that the series is deformed by south-verging folds.

Stop 5-6: $42^{\circ} 22.568^{\prime} N$ and $83^{\circ} 15.959^{\prime} E$

Diabase intruding in thin-bedded red cherts.

Day 6. Basement of Central Tianshan and Gangou ophiolitic mélange, north of Kumux

Stop 6-1: $42^{\circ} 178.705^{\prime} N$ and $88^{\circ} 28.556^{\prime} E$, on the G314 highway from Kumux to Toksun (South to North)

Augen orthogneiss and biotite-muscovite micaschists. The mean foliation trends N145E. A N-S to NW-SE striking mineral and stretching lineation can be observed on this foliation. Kinematic indicators such as asymmetric augen or sigma-type porphyroclasts systems show a top-to-the-N shearing. Muscovite yields poorly defined ${ }^{40} \mathrm{Ar} /{ }^{39} \mathrm{Ar}$ ages of $390-360 \mathrm{Ma}$ (Deng et al., 2006). The foliation and lineation are refolded by upright folds.

These metamorphic rocks are interpreted as the Proterozoic basement of the Central Tianshan Block, but the ductile deformation likely developed during the northward emplacement of the South Tianshan mélange (cf. the Yushugou klippe cropping out several kilometers Southward). The post- folial upward folding post dates the South Tianshan mélange emplacement.

Stop 6-2: $42^{\circ} 29.634^{\prime} N$ and $88^{\circ} 39.440^{\prime}$ E along the road G314 from Kumux to Toksun, exit the main road from the 189.6th $\mathrm{km}$ and run to the west for $4.7 \mathrm{~km}$

Gangou ophiolitic mélange: blocks of serpentinite, rodingite, chert within a matrix made of schistose tuff and greywacke. The ophiolitic mélange is intruded by SE-trending K-rich granitic dykes. This mélange is equivalent to that observed a few kilometres to the west, at stop 2-3. Due to the intense shearing related to the Permian strikeslip faulting, the mélange matrix is undated. However, it is likely of pre-Visean age as, at Mishigou, the same mélange is unconformably covered by Visean conglomerate.

\section{Day 7. Aiwergou section: Carboniferous olistostrome of North Tianshan, Permian alluvial sedimentary rocks and Triassic unconformity}

South of Urumqi, along the Road S103, this section is subparallel to the Houxia section. But the chaotic sedimentary rocks interpreted as deposited in an accretionary complex are better developed. We shall observe Carboniferous pebbly mudstones, olistostrome with chert or siliceous mudstone blocks. These rocks are interpreted as trench-fill sediments formed in the accretionary prism related to a south-directed subduction in front of the North Tianshan arc. 

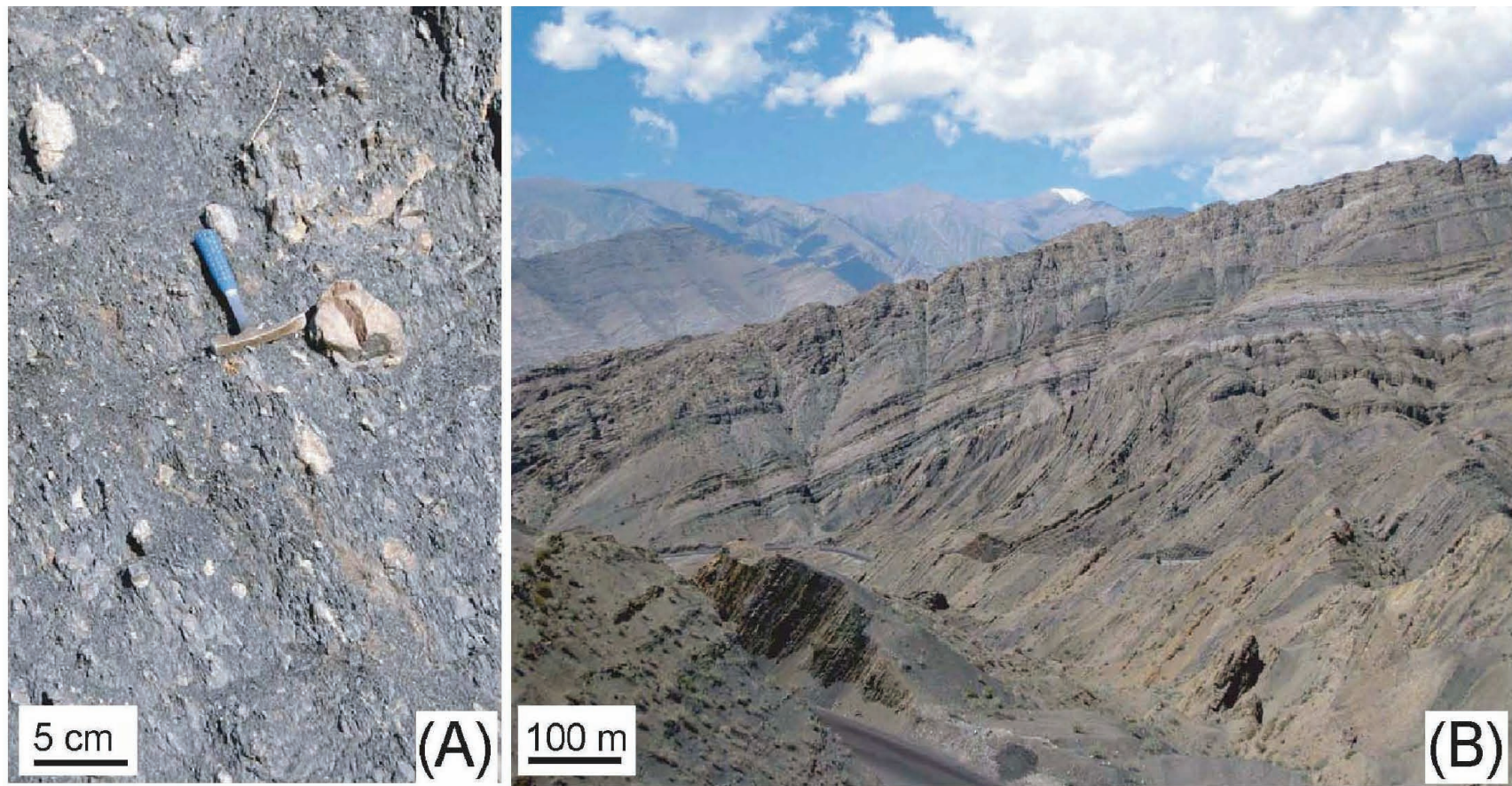

Figure 13. Field pictures of the outcrops observed in Aiwergou section.A. Pebbly mudstone with $C_{2}$ age; B. Late Triassic terrigeneous rocks unconformably overlying on the Late Permian rocks

Stop 7-1: $43^{\circ} 18.839^{\prime} N$ and $87^{\circ} 38.008^{\prime} E$, near Milestone 43

Pebbly mudstone with black matrix enclosing centimeter to plurimeter blocks of sandstone, pyroclastite, chert and limestone (Fig. 13A). The pervasive slaty cleavage is oriented N110E N65.

\section{Stop 7-2: Milestone 50 of the Road 5103}

Block-in-matrix series with siliceous mudstone, chert, limestone olistoliths within the mudstone matrix.

\section{Stop 7-3: Panorama Aiwergou, Road Z401 Milestone 2}

View of subvertical Late Permian conglomerates overlie by Late Triassic terrigeneous rocks. In the southern background, Jurassic sandstone and mudstone overly the Late Triassic beds. The southernmost mountains are formed by Carboniferous volcanic rocks belonging to the North Tianshan arc (Figs. 13B, 14).
Stop 7-4: in the curve of Road Z401, Milestone 6

The unconformity of Late Permian sandstone and conglomerate with pebbles of granite, andesite, rhyolite, quartz upon the Carboniferous rocks cannot be directly observed there. The Late Permian rocks are deformed by folds with steeply plunging axes. This folding event took place before the deposition of Early Triassic conglomerates.

\section{Stop 7-5: $43^{\circ} 00.894^{\prime} N$ and $87^{\circ} 33.571^{\prime} E$}

Late Triassic sandstone and conglomerate containing pebbles of quartz, volcanic rocks and sandstone. The base of the conglomerate exhibits erosional channels. These fluvial deposits unconformably overlie folded Permian sandstone and black carbonaceous mudstone with plant remains. The Late Permian, Triassic and Jurassic terrigeneous deposits or volcanic rocks that unconformably cover the Carboniferous-Early Permian arc rocks are continental formations.

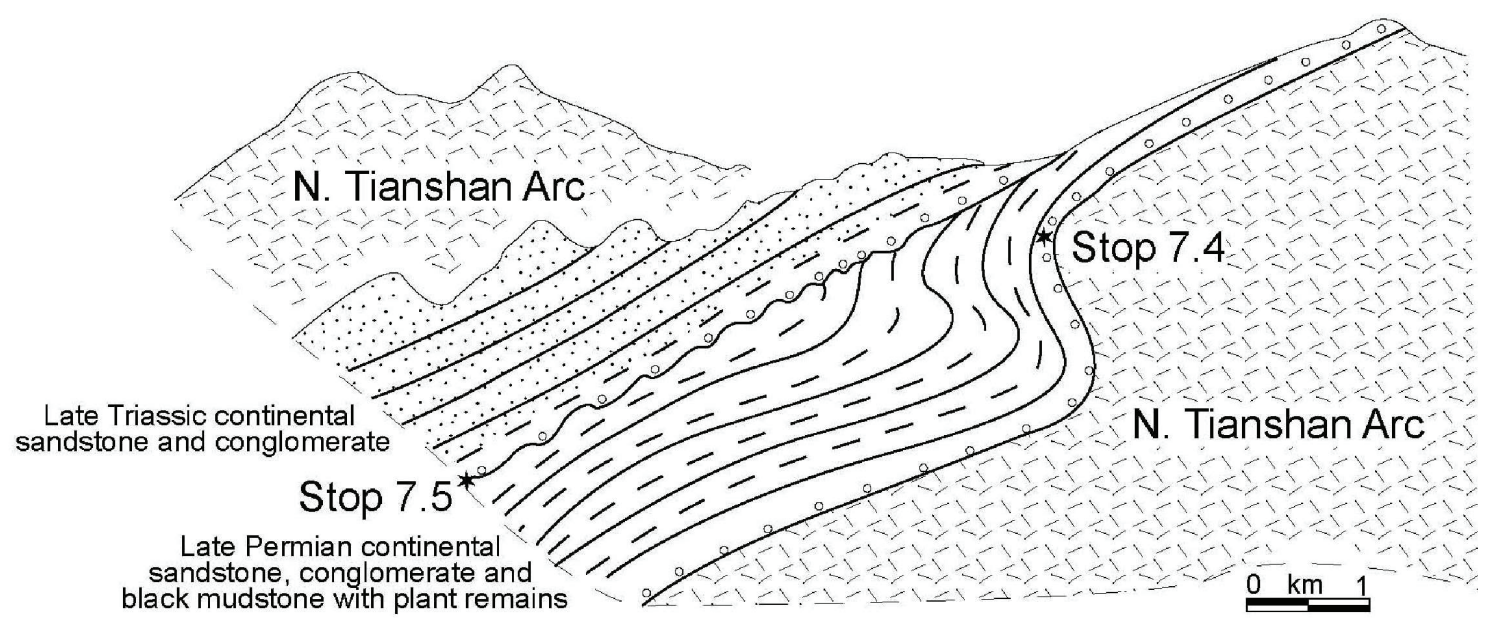

Figure 14. Schematic cross section of the Aiwergou section. 
Together with some other lines of evidence found in the Southwestern Chinese Tianshan such as Late Permian radiolarian fossils ( $\mathrm{Li}$ et al. 2002, 2005), UHP eclogite yielding a Late Triassic age (Zhang et al. 2007) and Permian Alaskan-type granite, the Late Triassic unconformity led Xiao et al. $(2008,2009)$ to conclude that the northward subduction between Tarim and Yili blocks was completed in the Triassic. However, due to its continental sedimentary environment, this unconformity might be also interpreted as a sedimentary response of a post-collisional tectonic event.

\section{Day 8 (not done). Urumqi-Houxia-Bingdaban section}

In this section along the Road G216, we shall observe the Carboniferous-Early Permian sedimentary rocks of the North Tianshan active margin (andesitic-rhyolitic rocks dated at 272 \pm 4 Ma using zircon U-Pb SHRIMP method by Yang et al. 2006, turbidites, chert or siliceous mudstone and pebbly mudstone). North of the Bingdaban pass (Fig. 5), augen gneiss, foliated, or even mylonitic, metavolcano-sedimentary rocks with dextral kinematic can be observed as well.

Stop 8-1: $43^{\circ} 22.429^{\prime} N$ and $87^{\circ} 12.426^{\prime} E$, between milestones 737 and 738

Black mudstone, laminated siliceous mudstone and discontinuous sandstone beds. The bedding $\left(\mathrm{S}_{0}\right)$ is folded by upright folds. En echelon tension gashes indicate a south directed faulting.

Stop 8-2: $43^{\circ} 21.955^{\prime} \mathrm{N}$ and $87^{\circ} 12.108^{\prime} \mathrm{E}$, after the bridge.

Subvertical turbidite. Graded bedding and cross lamination show both top-to-the north and top-to-the-south polarity. These sedimentological features argue for tight upright folds.

Stop 8-3: Immediately north of Houxia, between milestones 744 and 745

View of the flat-lying unconformity of Jurassic over Carboniferous, and open folds.

\section{Stop 8-4 (optional): $43^{\circ} 07.983^{\prime} N$ and $87^{\circ} 04.633^{\prime} E$}

Carboniferous limestone series indicates by vertical bedding $\mathrm{S}_{0}$. The present contact with the volcanic series is tectonic, but this limestone may be stratigraphically associated with the volcanics. The series is very similar to the sequence of the Yili arc.

Stop 8-5: $43^{\circ} 07.367^{\prime} N$ and $87^{\circ} 03801^{\prime} E$

Red mudstone and andesitic lava of Late Carboniferous age. This site has been studied for paleomagnetic studies (Wang et al., 2007b).

Stop 8-6: $43^{\circ} 07.13^{\prime} N$ and $87^{\circ} 03.044^{\prime} E$, south of the "Red May" bridge, milestone 774

Fine grained diorite with skarn xenoliths. The diorite is locally mylonitic with steeply south-dipping foliation.

\section{Stop 8-7: $43^{\circ} 06.88^{\prime} N$ and $87^{\circ} 01.009^{\prime} E$}

Subvertical mudstone-phyllite with a well marked subhorizontal mineral and stretching lineation. In thin section sheared andalusite can be observed and indicates dextral shearing. This site corresponds to the North Tianshan Fault (NTF, Wang et al. 2006) and the Main Tianshan shear zone (MTSZ, Laurent-Charvet et al. 2003). Whole-

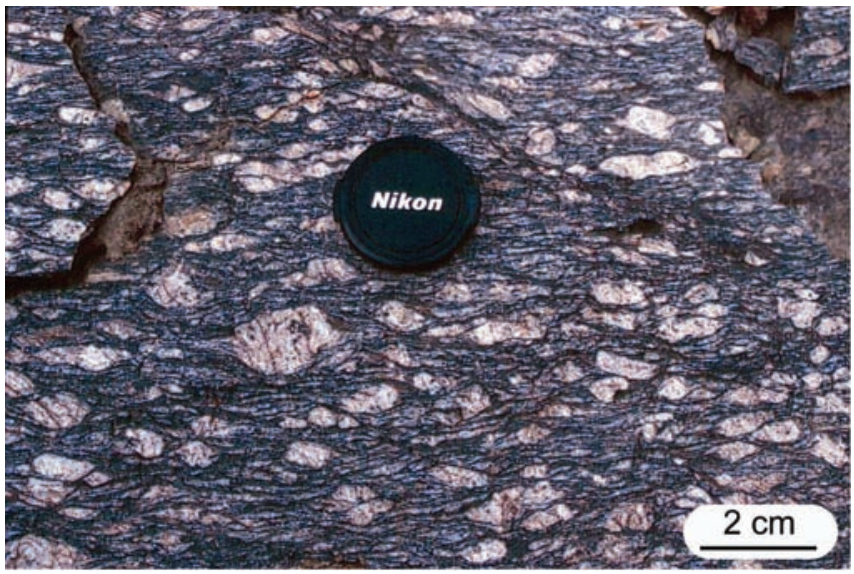

Figure 15. Porphyritic granite deformed by Permian dextral shearing at Bingdaban (Stop 8.8).

rock ${ }^{40} \mathrm{Ar} /{ }^{39} \mathrm{Ar}$ dating of mylonitic phyllite yielded ages of 275-263 Ma (de Jong et al. 2009).

Stop 8-7' (optional): $43^{\circ} 06.88^{\prime} \mathrm{N}$ and $87^{\circ} 00.482^{\prime} \mathrm{E}$, eastern side of the river

Mylonitic mica-quartz schist with steep foliation and subhorizontal stretching lineation. These rocks are the most deformed ones in the shear zone.

Stop 8-8: $43^{\circ} 05.951^{\prime} N$ and $86^{\circ} 50.306^{\prime} E$, in the curves in front of the glacier, Milestone 798

Augen gneiss with dextral kinematic indicators. The protolith is a porphyritic granodiorite dated at $442 \pm 4$ Ma by SHRIMP method on zircon with inherited zircons of up to $1788 \mathrm{Ma}$ (Zhu and Song 2006). But Yang et al. (2008) interpret this augen gneiss as the basement of North Tianshan according to their new zircon U-Pb geochronological date of $956 \pm 11$ Ma.

\section{Stop 8-9: Bingdaban (elevation $4280 \mathrm{~m}$ )}

Landscape on the North Tianshan range. This domain is a Carboniferous magmatic arc due to a southward subduction of the North Tianshan Oceanic basin. The arc has been afterward sheared by dextral wrenching along the MTSZ during the Permian (LaurentCharvet et al., 2002, 2003).

\section{References}

Charvet, J., Shu, L., and Laurent-Charvet, S., 2007, Paleozoic structural and geodynamic evolution of eastern Tianshan (NW China): welding of the Tarim and Junggar plates, Episodes, v. 30, pp. 162-186.

de Jong, K., Wang, B., Faure, M., Shu, L., Cluzel, D., Charvet, J., Ruffet, G., and Chen, Y., 2009, New ${ }^{40} \mathrm{Ar} /{ }^{39} \mathrm{Ar}$ age constraints on the Late Palaeozoic tectonic evolution of the western Tianshan (Xinjiang, northwestern China), with emphasis on Permian fluid ingress, International Journal of Earth Sciences, v. 98, pp. 1239-1258.

Deng, S.T., Guo, Z.J., Zhang, Z.C., and Liao, G.H., 2006, Timing of the formation of the Sangshuyuanzi ductile shear zone in the central segment of the South Tianshan and its tectonic significance, Geology in China, v. 33, pp. 641-647 (in Chinese with English abstract).

Deng, X.L., Shu, L.S., Zhu, W.B., Ma, D.S., and Wang, B., 2008, Precambrian tectonism, magmatism, deformation and geochronology of ignenous rocks 
in the Xingdi fault zone, Xinjiang, Acta Petrologica Sinica 24, pp. 28002808 (in Chinese with English abstract).

Gao, J., Li, M.S., Xiao, X.C., Tan, Y.Q., and He, G.Q., 1998, Paleozoic tectonic evolution of the Tianshan Orogen, northwestern China, Tectonophysics, v. 287 , pp. $213-231$.

Guo, Z.J., Ma, R.S., and Guo, L.Z., 1993, A comparative study on three ophiolitic mélange belts in eastern Xinjiang, Geological Review, v. 39, pp. 236-247 (in Chinese with English abstract).

Laurent-Charvet, S., Charvet, J., Shu, L.S., Ma, R.S., and Lu, H.F., 2002, Palaeozoic late collisional strike slip deformations in Tianshan and Altay, eastern Xinjiang, NW China, Terra Nova, v. 14, pp. 249256.

Laurent-Charvet, S., Charvet, J., Monie, P., and Shu, L.S., 2003, Late Paleozoic strike-slip shear zones in eastern Central Asia (NW China): new structural and geochronological data, Tectonics, v. 22, pp. 1099-1101.

Li, Q.G., Liu, S.W., Wang, Z.Q., Han, B.F., Shu, G.M., and Wang, T., 2008, Electron microprobe Monazite geochronological constraints on the Late Paleozoic tectonothermal evolution in the Chinese Tianshan, Journal of Geological Society London, v. 165, pp. 511-522.

Li, X.D., Xiao, W.J., and Zhou, Z.L., 2004, ${ }^{40} \mathrm{Ar} /{ }^{39} \mathrm{Ar}$ age determination on the Late Devonian tectonic event along the southern margin of the South Tianshan Mountains and its significance, Acta Geologica Sinica, v. 20, pp. 691-696 (in Chinese with English abstract).

Li, Y.J., Wang, Z.M., Wu, H.R., Huang, Z.B., Tan, Z.J., Luo, and J.C., 2002, New discovery of radiolarian fossils from Aiktik Group in Southern Tianshan, Acta geologica sinica, v. 76, pp. 146-154.

Li, Y.J., Sun, L.D., Wu, H.R., Zhang, G.Y., Wang, G.L., and Peng, G.X., 2005, Permo-Carboniferous radiolarians from the Wupata'erkan group, Western South Tianshan, Xinjiang, China, Acta Geologica Sinica, v. 79, pp. 1623.

Long, L.L., Gao, J., Xiong, X.M., and Qian, Q., 2006, The geochemical characteristics and the age of the Kule Lake ophiolite in the southern Tianshan, Acta Petrologica Sinica, v. 22, pp. 65-73 (in Chinese with English abstract).

Ma, R.S., Wang, C.F., and Ye, S.F., 1993, Tectonic framework crustal evolution of Eastern Tianshan Mountains, Publishing House of Nanjing University, Nanjing, 225pp (in Chinese with English abstract).

Shi, Y.R., Liu, D.Y., and Zhang, Q., 2007, SHRIMP zircon U-Pb dating of the Gangou granitoids, Central Tianshan Mountains, Northwest China and tectonic significances, Chinese Science Bulletin, v. 52, pp. 15071516.

Shu, L.S., Yu, J.H., and Charvet, J., 2004, Geological, geochronological and geochemical features of granulites in the Eastern Tianshan, NW China, Journal of Asian Earth Sciences, v. 24, pp.25-41.

Shu, L.S., Zhu, W.B., Wang, B., Faure, M., Charvet, J., and Cluzel, D., 2005, The post-collision intracontinental rifting and olistostrome on the southern slope of Bogda Mountains, Xinjiang, Acta Petrologica Sinica, v. 21, pp. 25-36 (in Chinese with English abstract).

Shu, L.S., Wang, B., Zhu, W.B., Guo, Z.J., Charvet, J., and Zhang, Y., 2010, Tectonic features of the Chinese Tianshan belt during Early Permian: New Insights from Baiyanggou olistostrome and volcanic rocks, International Journal of Earth Sciences, in press.

Tang, Y., Gao, J., Zhang, M., and Wang, J., 1995, The ophiolite blueschist in the southwestern Tianshan orogenic belt Xinjiang, NW China, Geological publishing house, Beijing, 133pp (in Chinese with English abstract).

Wang, B., 2006, Paleozoic geodynamic evolution of Yili Block in West Chinese
Tianshan, PhD thesis, Nanjing University-Orleans University, NanjingOrleans, 153p.

Wang, B., Chen, Y., Zhan, S., Shu, L.S., Faure, M., Cluzel, D., Charvet, J., and Laurent-Charvet, S., 2007b, Primary Carboniferous and Permian paleomagnetic results from the Yili Block (NW China) and their implications on the geodynamic evolution of Chinese Tianshan Belt, Earth and Planetary Science Letters, v. 263, pp. 288-308.

Wang, B., Cluzel, D., Shu, L.S., Faure, M., Charvet, J., Chen, Y., Meffre, S., and de Jong, K., 2009, Evolution of calc-alkaline to alkaline magmatism through Carboniferous convergence to Permian transcurrent tectonics, western Chinese Tianshan, International Journal of Earth Sciences, v. 98 , pp. $1275-1298$.

Wang, R.S., Zhou, D.W., Wang, Y., Wang, J.L., Sang, H.Q., and Zhang, R.H., 2003, Geochronology for the multi-stage metamorphism of high-pressure terrain of granulite facies from Yushugou area, south Tianshan, Acta Petrologica Sinica, v. 19, pp. 452-460 (in Chinese with English abstract).

Xiao, W.J., Han, C.M., Yuan, C., Sun, M., Lin, S.F., Chen, H., Li, Z., Li, J., and Sun, S., 2008, Middle Cambrian to Permian subduction-related accretionary orogenesis of Northern Xinjiang, NW China: Implications for the tectonic evolution of central Asia, Journal of Asian Earth Sciences, v. 32, pp. 102-117.

Xiao, W.J., Windley, B.F., Han, C.M., Yuan, C., Sun, M., Li, J.L., and Sun, S., 2009, End Permian to mid-Triassic termination of the southern Central Asian Orogenic Belt, International Journal Earth Sciences, v. 98, pp. 1189-1217.

Yang, T.N., Li, J.Y., Sun, G.H., and Wang, Y.B., 2006, Earlier Devonian active continental arc in Central Tianshan: evidence of geochemical analyses Zircon SHRIMP dating on mylonitized granitic rock, Acta Petrologica Sinica, v. 22, pp. 41-48 (In Chinese with English abstract).

Yang, T.N., Li, J.Y., Sun, G.H., and Wang, Y.B., 2008, Mesoproterozoic Continental Arc Type Granite in the Central Tianshan Mountains: Zircon SHRIMP U-Pb Dating and Geochemical Analyses, Acta Geologica Sinica (English Edition), v. 82, pp. 801-809.

Yin, A., and Nie, S., 1996, A Phanerozoic palinspastic reconstruction of China its neighboring regions. In: Yin, A., Harrison, T.M. (eds)., Tectonic Evolution of Asia, Cambridge Univ Press, Cambridge, United Kingdom, pp. 442-485

Zhang, L.F., Ai, Y.L., Li, X.P., Rubatto, D., Song, B., Williams, S., Song, S.G., Ellis, D., and Liou, J.G., 2007, Triassic collision of western Tianshan orogenic belt, China: Evidence from SHRIMP U-Pb dating of zircon from HP/UHP eclogitic rocks, Lithos, v. 96, pp. 266-280.

Zhou, D.W., Su, L., and Jian, P., 2004, Zircon U-Pb SHRIMP ages of Yushugou ophiolitic terrane in Southern Tianshan and their tectonic implications, Chinese Science Bulletin, v. 49, pp. 1415-1419.

Zhu, Y.F, and Song, B., 2006, Petrology and SHRIMP chronology mylonitized Tianger granite, Xinjiang: also about the dating on hydrothermal zircon tim in granite, Acta Petrologica Sinica, v. 22, pp. 135-144 (in Chinese with English abstract).

Zhu, Z.X., 2007, The geological components and tectonic evolution of South Tianshan, Xinjiang, PhD Dissertation, Chinese Academy of Geological Sciences, Beijing, 210pp.

Zhu, Z.X., Li, J.Y., Dong, L.H., Wang, K.Z., Liu, G.Z., Li, Y.P., and Liu, Z.T., 2008, Age determination and geological significance of Devonian granitic intrusions in Seriyakeyilake region, northern margin of Tarim basin, Xinjiang, Acta Petrologica Sinica, v. 24, pp. 971-976 (in Chinese with English abstract). 


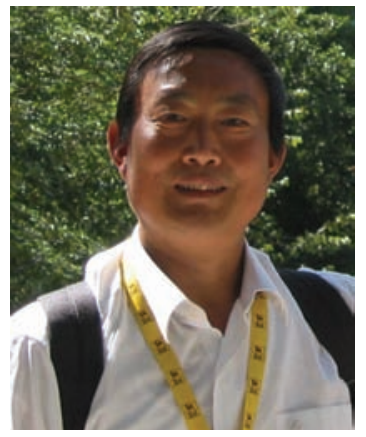

Qingchen Wang is currently the Secretary-General of the China National Committee for SCL/ILP, and the Chairman of the International Lithosphere Program project TOPOCENTRAL-ASIA (CC-1/4). He got his Ph.D. from, Chinese Academy of Sciences in 1985. He majors in petrology and tectonics, and studies geodynamics of orogenic belts and sedimentary basins.

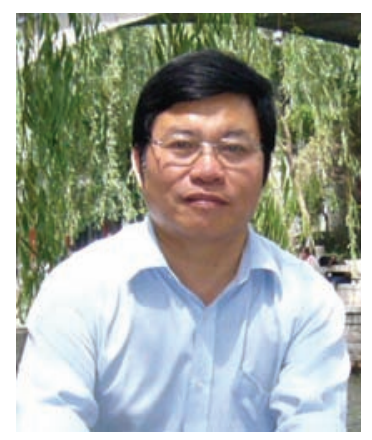

Liangshu Shu is Professor of structural geology at Nanjing University, China. His major interests are geo-tectonics and structural geology, especially the deformation and evolution of crustal rocks. Since 1980's, he has been studying plate tectonics and the geodynamic evolution of the orogenic belt in the Jiangnan, Cathaysia and Tianshan areas.

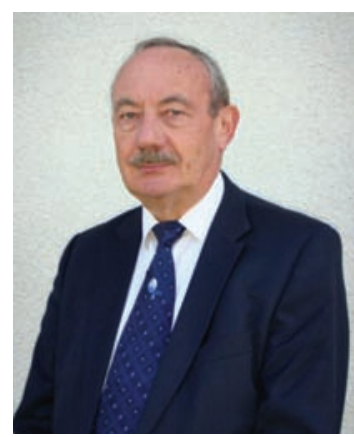

Jacques Charvet is emeritus Professor at Orléans University. He received his Doctor's degree from Lille University in 1978. His main scientific interest is on tectonics and geodynamics, mountain building, and ore deposits. After field studies in various areas: Dinarides, Pyrénées, and South Iberian Pyrite Belt in Europe; western Cordillera in North America; Brazilian Espinhaço Belt in South America; SW Japan. He concentrated his research on the geology of China during the last two decades.

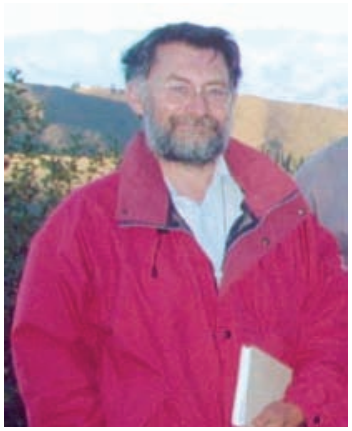

Michel Faure is professor of structural geology and tectonics in Orléans University. His scientific work is dedicated to the geodynamic evolution of mountain belts. He investigates the tectonic setting of metamorphic and magmatic roots of orogens from lithospheric convergence to collision, exhumation of High Pressure and Ultra-High Pressure tectonic units and crustal melting.

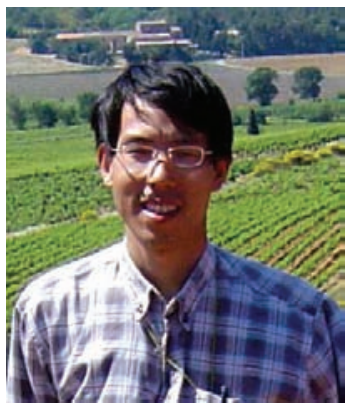

Bo Wang is associate professor at Nanjing University (China). He received his Ph.D. degrees on structural geology from Nanjing University and on geodynamics from Orléans University (France), respectively. His research interests are on the tectonic evolution of the Tianshan Belt and recently on other mountain belts of the Central Asia.

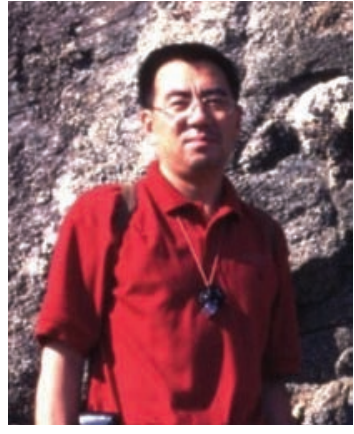

Wei Lin is Professor of structural geology at the Institute of Geology and Geophysics, Chinese Academy of Sciences. He obtained his PhD. degree in Orleans University (France). In recent years, his research interest focuses on the structural analysis, tectonic evolution and geodynamics of the Paleoproterozoic belts in the North China craton and the South China block, the HP and UHP orogenic belt of Central China and the Mesozoic to Cenozoic lithosphere thinning in the North China Craton. 